\title{
Projected Change-_River Flow and Urban Drainage
}

\author{
Patrick Willems and Benjamin Lloyd-Hughes
}

\begin{abstract}
Hydrological extremes, largely driven by precipitation, are projected to become more intense within the North Sea region. Quantifying future changes in hydrology is difficult, mainly due to the high uncertainties in future greenhouse gas emissions and climate model output. Nevertheless, models suggest that peak river flow in many rivers may be up to $30 \%$ higher by 2100 , and in some rivers even higher. The greatest increases are projected for the northern basins. Earlier spring floods are projected for snow-dominated catchments but this does not always cause an increase in peak flows; peak flows may decrease if higher spring temperatures lead to reduced snow storage. An increase in rain-fed flow in winter and autumn may change the seasonality of peak flows and floods. The proximity of a river basin to the ocean is also important; the closer the two the greater the potential damping of any climate change effect. In urban catchments, the specific characteristics of the drainage system will dictate whether the net result of the climate change effect, for example the projected increase in short-duration rainfall extremes, is to damp or amplify the impact of this change in precipitation. The response in terms of sewer flood and overflow frequencies and volumes is highly non-linear. The combined impact of climate change and increased urbanisation in some parts of the North Sea region could result in as much as a four-fold increase in sewer overflow volumes.
\end{abstract}

\subsection{Introduction}

The hydrological cycle is an intrinsic part of the climate system. Changes within the climate directly and indirectly influence the components of the hydrological cycle. As an illustration, climate change may alter river regimes directly through changes in rainfall, and indirectly through changes

Electronic supplementary material Supplementary material is available in the online version of this chapter at 10.1007/978-3-31939745-0_7.

\section{P. Willems $(\bowtie)$}

Department of Civil Engineering, KU Leuven, Leuven, Belgium e-mail: patrick.willems@bwk.kuleuven.be

B. Lloyd-Hughes $(\square)$

Walker Institute for Climate System Research,

University of Reading, Reading, UK

e-mail: B.LloydHughes@ reading.ac.uk in temperature, which may change evaporation and affect snow melt. Differences in rainfall intensity may alter flood hazards through changes in peak discharge and erosion. Additionally, temperature changes, especially during summer, affect the soil water content and groundwater recharge, and thus water input (from ground water and base flow) to rivers. As a result, the risk of low flow alters, which can also impact on water quality, navigation and water availability for agricultural and industrial purposes. In short, climate change affects or controls inputs, losses, storage and transfer into the hydrological system (IPCC 2014). Whether and in what way this is the case for the North Sea region is the focus of this chapter, based on a review of available studies on climate change impacts on river flow in the North Sea region. Impacts in urban catchments are also considered.

To assess the potential impacts of climate change on river flow, methods are applied that make use of both climate models and hydrological models. Climate models simulate 
the climate system to determine the response to changes in greenhouse gases in the atmosphere (see Chap. 5) while hydrological models simulate the climate change effect on the water cycle. To assess the potential impact of climate change on river flow, climate change signals are used to alter the input to hydrological models that aim to simulate the climate-driven response in the hydrological environment. The strength of the changes depends on the temporal and spatial scales being examined.

River flow may be affected by changes in land use, ground water abstraction, hydraulic structures (such as reservoirs) along the river course, and urbanisation (see Sect. 7.3.3), among others; none of which are directly linked to climate change. Such features mean not all climate-driven hydrological impacts are easily discernible, and so caution is necessary when attributing hydrological change to 'climate change impact'; see also Chap. 5.

\subsection{Methodology}

\subsubsection{Temporal and Spatial Scales}

Uncertainties in climate and hydrological models mean caution must be applied in using the model output to project climate-driven impacts on river flow. This is especially the case for studying local hydrological impacts. Local climates are represented in regional climate models (RCMs) at the spatial resolution of the RCMs, and are less reliable than the coarser resolution climate data obtained from the same RCMs or from global climate models (GCMs). However, the reliability of climate models is improving due to the ongoing research in climate science (see the Supplement S7 to this chapter). The highest resolution RCMs are now in the range of a few tens of kilometres which reduces the mismatch with hydrological models that often operate at resolutions of a few kilometres or less. High resolution models, however, do not completely resolve the physics of the climate system so climate model output still requires further scrutiny before use in regional climate studies.

Although the natural processes addressed in climate and hydrological models are closely linked, because climate science and hydrology are separate disciplines the technical aspects of these different disciplines require an interface linking the respective models. This interface allows a realistic transfer of information between climatic and hydrologic simulations. Methods at the interface range from the direct use of climate model output to correct for bias (systematic over- or underestimations) before use. However, direct use is rarely implemented due to the bias in climate models. Another major interfacing issue is the need for high resolution data in many hydrological applications, both in space and time. Finer-resolution climate models imply a developmental and computational burden which translates to higher resources, in time and money. While efforts to increase the resolution of GCMs and RCMs continue (e.g. HiGEM, Shaffrey et al. 2009; Kendon et al. 2012) the current state-of-the-art is well short of the requirements for local hydrological modelling.

These two main interfacing problems are met by applying statistical downscaling to the climate model output, ultimately in combination with bias correction. The aims of the bias correction and statistical downscaling are to eliminate systematic errors between the climate model output and the corresponding meteorological variables at the finer hydrological impact scales and/or to convert the climate model output to the finer-scale variables using statistical methods (Maraun et al. 2010; Gudmundsson et al. 2012a). More discussion on the mismatch of scales, statistical downscaling and bias correction is available in the Supplement S7. These downscaling and bias correction methods have increased data availability for hydrological assessments. Different approaches have been developed. Several have been applied in the North Sea region, depending on the area, type of hydrological impact, approach and experience of the modeller and available resources, among others.

\subsubsection{Analysis}

Determining the climate-driven change in river flow typically includes four steps: evaluating the climate models; downscaling/bias correction of the hydrological variables from the climate scenarios; converting climate change signals/perturbations to hydrological parameters; and simulating the hydrological climate change effect.

Different types of hydrological models have been used for studying the impact of climate change, depending on the scale and the processes. Conceptual rainfall-runoff models have been widely applied to individual catchments because of their ease of use and calibration (limited number of model parameters) and because they provide overall runoff estimates at the scale of a catchment or sub-catchment (see Supplement S7 for examples). In order to capture the spatial variability of the hydrological response in larger river basins or regions, spatially-distributed hydrological balance models have been applied. These can be of a conceptual nature or more detailed, depending on the types of impacts studied (e.g. Shabalova et al. 2003; Lenderink et al. 2007; Thompson et al. 2009; Bell et al. 2012; Huang et al. 2013). At the continental and global scale, land surface models and coarse-scale global water balance models are used, such as at the scale of Europe (e.g. Dankers and Feyen 2008; Feyen and Dankers 2009; Prudhomme et al. 2012) or the entire globe (e.g. Arnell and Gosling 2016; Dankers et al. 2014).

Hydrological impact results are typically evaluated for mean annual or seasonal volumes, but also for flow extremes 
(peak flows and low flows). The latter are of particular relevance for water management, given that they are fundamental to flood and water scarcity risks. Peak and low flow extremes for current and future climatic conditions are typically compared for quantiles, hence for given exceedance probabilities or return periods. Such quantiles, for example the 100-year peak flow, form the basis of water engineering design statistics. They can be obtained empirically from the independent extreme flows extracted from the simulated time series (possible only up to the length of the time series), or after extreme-value analysis (required for extrapolating beyond the length of the time series). Bastola et al. (2011), Arnell and Gosling (2016), Dankers et al. (2014), and Smith et al. (2014), for example, defined peak flows as annual maximum flows and extrapolated these based on the Generalized Extreme Value (GEV) distribution. Lawrence and Hisdal (2011) did the same but used the Gumbel distribution as a special case of the GEV, and Kay and Jones (2012) made use of a generalised logistic distribution. Willems (2013a) selected independent peak flows from a time series by means of hydrological independence criteria to obtain a peak-over-threshold or partial-duration-series. These typically follow the Generalized Pareto Distribution (GPD), or the exponential distribution as a special case. The statistical uncertainty in estimates of large return periods (e.g. 100 years) may be considerable, however, especially when based on relatively short time series (typically 30 years for climate model results) (Brisson et al. 2015). Using information on flood thresholds or hydraulic flood modelling, the flow extremes can be related to flood hazard (e.g. return period of flooding) or even flood risk after considering functions describing the regional or local relationship between flood flow or depth and the flood consequences (Feyen et al. 2012; Ward et al. 2013; Arnell and Gosling 2016).

For impact analysis on urban drainage (sewer floods), because of the quick response of such systems to rainfall, changes in short-duration extremes (hourly to sub-hourly) are considered. These changes are propagated to changes in sewer flow by full hydrodynamic or conceptual sewer models; a recent state-of-the-art review of methods, difficulties/pitfalls, and impact results was made by Willems et al. $(2012 \mathrm{a}, \mathrm{b})$

As well as changes in rainfall and evaporation, for impact analysis on water quality in urban drainage systems and along rivers, changes in other variables must also be considered. Impacts on water quality are not only controlled by changes in rainfall, but also by (changes in the length of) dry periods. In the case of longer dry periods in north-western Europe, river pollution will be less diluted and river water quality will deteriorate. Some sources of river pollution might even increase, such as pollution originating from sewer overflows.
Along sewer systems, longer dry periods cause water and wastewater to stay for longer in the sewer pipes. Particularly in the low and flat North Sea region, this will lead to higher sewer solids sedimentation (Bates et al. 2008). An increase in short-duration rainfall extremes will not only increase peak runoff discharges but will also increase wash off from surfaces (impermeable and permeable) in the sewer catchment. An increase in runoff and sewer peak flows, would increase the frequency of sewer overflows or the spilling of storm- and/or waste-water into the receiving river. These effects are studied by integrated urban drainage models comprising the sewer system, wastewater treatment plant and receiving river. Using such a model, Astaraie-Imani et al. (2012) studied the impact of climate change (and urbanisation) on the receiving water quality of an urban river for dissolved oxygen and ammonium using a semi-real case study in the UK. Another application, but for a catchment in Belgium and limited to the flow impacts of sewer systems on receiving rivers was reported by Keupers and Willems (2013). Other types of climatic change effect along sewer systems include changes in temperature, which affect sewer quality processes (Ashley et al. 2008), risk of sulphide production in the sewer pipes, and increased odour problems; as well as increased sewer floods and sewer overflows because of changes in snowmelt patterns in mountainous regions, sea-level rise in low-lying coastal areas, inflow of groundwater during the wet season, and increased leakage of wastewater into the soil during the dry season, among others.

Whatever model type is applied, it is necessary to be aware that parameters calibrated for historical periods may not be valid under a changing climate. For instance, it is known that under dry conditions, soil moisture parameters are likely to change, which may affect the hydrological processes by introducing other complex mechanisms (Diaz-Nieto and Wilby 2005). One way of understanding the changes is to assess longer hydrological and meteorological records with significantly different changes in climate and land use (Refsgaard et al. 2014). However, sufficiently long time series (e.g. over 100 years) are often not available to evaluate this assumption.

It is also necessary to be aware of the limitations of the models in modelling particular types of extremes (e.g. high flow, low flow). For that reason, methods have been developed that explicitly validate model performance for high and low extremes; see Seibert (2003), Willems (2009), and Karlsson et al. (2013). Van Steenbergen and Willems (2012) proposed a data-based method to validate the performance of hydrological models in describing changes in peak flow under changes in rainfall extremes, prior to their use for climate change impact investigations. Vansteenkiste et al. (2013, 2014) compared different hydrological models and concluded that the impact results of climate scenarios might significantly differ depending on the model structure and 
underlying assumptions, especially for low flow. Gosling et al. (2011) applied two types of distributed hydrological model to different catchments, including the Harper's Brook catchment in the UK, to analyse the impact uncertainty from seven GCM runs. Both models simulated similar climate change signals, but differences occurred in the mean annual runoff, the seasonality of runoff, and the magnitude of changes in extreme monthly runoff. Also, Bastola et al. (2011) emphasised the importance of incorporating hydrological model structure and parameter uncertainty in estimating climate change impacts on flood quantiles. They found that the highest model uncertainty is associated with low frequency flood quantiles and with models that use nonlinear surface storage structures. Lawrence et al. (2009) investigated model parameter calibration uncertainty for the Nordic HBV model calibrated to 115 Norwegian catchments. This was done by selecting 25 parameter sets that lead to almost equal model performance. In general, however, hydrological model related uncertainty is low compared to climate model uncertainty (Minville et al. 2008; Kay et al. 2009). The latter is shown by comparing evaluations of climate and hydrological model performance against observations; however limited to historical (climate) conditions. For drought, Prudhomme et al. (2014) concluded that global hydrological models show a higher uncertainty than global climate models. At the catchment scale, it appears that hydrological model impact uncertainties are greater for low flow than for peak flow (Vansteenkiste et al. 2013, 2014), but are still less than from climate models.

\subsubsection{Scenarios}

Owing to the high uncertainties involved in the parameterisations of the climate models and the future greenhouse gas scenarios (see Supplement S7), it is better to apply a broad ensemble set of climate model simulations. Uncertainty in the future projections can thus be partly accounted for (Palmer and Räisänen 2002; Tebaldi et al. 2005; Collins 2007; Smith et al. 2009; Semenov and Stratonovitch 2010). Use of ensemble-based probabilistic projections has been proposed but would raises questions and difficulties for impact modellers (New et al. 2007). Linking probabilities to future scenarios is a commendable idea, but it is not clear how the use of probabilities would maintain internal consistency, which is a key requirement for impact analysis. It is pragmatic, therefore, to make use of existing climate change impact methods, albeit with improvements.

Any ensemble of climate model runs best includes a broad set of different climate models and greenhouse gas scenarios (SRES, RCP; see Supplement S7). Note in this respect that hydrological impact analyses of climate change to date have largely ignored the most pessimistic projections for climate change such as the SRES A1FI scenario. It has been argued that emission trends since 2000 are in line with the A1FI projections made in the 1990s (Raupach et al. 2007), which means that the A1FI scenario is becoming more plausible and the most likely projected high flows could be even higher than those reported here. Recent evidence also suggests that GCM projections underestimate the amount of warming that is already being observed in western Europe (van Oldenborgh et al. 2009).

The hydrological impact results reported in this chapter are primarily based on the SRES scenarios. Hydrological impact results for the newer RCP-based climate scenarios were still limited at the time this chapter was drafted (first global results exist: Dankers et al. 2014; Prudhomme et al. 2014), but it would be worth more extensively testing the change and consistency in impact results between the SRES and RCP-based scenarios.

In addition to uncertainties in the climate process modelling and greenhouse gas scenarios, the downscaling method used adds to uncertainty in the climate scenarios (see more discussion in the Supplement S7). Impact modelling based on large ensembles of climate model simulations under different downscaling assumptions remains difficult in practice because of the high computational costs associated with hydrological and hydraulic modelling. A pragmatic approach would be to summarise the different meteorological impact results of climate change in a limited set of (tailored) scenarios. Examples include the UKCIP02 (Hulme et al. 2002), UKWIR06 (Vidal and Wade 2008), and UKCP09 scenarios in the UK (Murphy et al. 2009), the KNMI'06 scenarios in the Netherlands (Van den Hurk et al. 2006; de Wit et al. 2007), and the CCI-HYDR scenarios in Belgium (Willems 2013a; Ntegeka et al. 2014).

Figure 7.1 illustrates how the CCI-HYDR high, mean and low scenarios for one particular season are based on the highest, average and lowest climate factors for the entire set of potential scenarios considered. The changes for different seasons are combined in different versions such that they lead to high, mean, and low impacts for specific (tailored) hydrological applications, for example winter floods, summer flash floods and summer low flows. This is the opposite of the KNMI'06 scenarios that are based on meteorological considerations only (Fig. 7.2, where scenarios W and G refer to higher or lower changes in temperature, and the scenarios $\mathrm{W}+$ and $\mathrm{G}+$ to stronger changes in atmospheric circulation).

\subsection{Projections}

\subsubsection{North Sea Region}

Numerous studies indicate that in north-western Europe a warmer climate may lead to an increase in intense rainfall 
Fig. 7.1 High-mean-low tailored climate scenarios to simplify the flood impact analysis based on an ensemble set of climate model simulations (here: factor change in daily rainfall quantiles from 1961-1990 to 2071-2100 for A2 and B2 SRES scenarios and all RCM runs available for Belgium from the EU PRUDENCE project; Ntegeka et al. 2014)

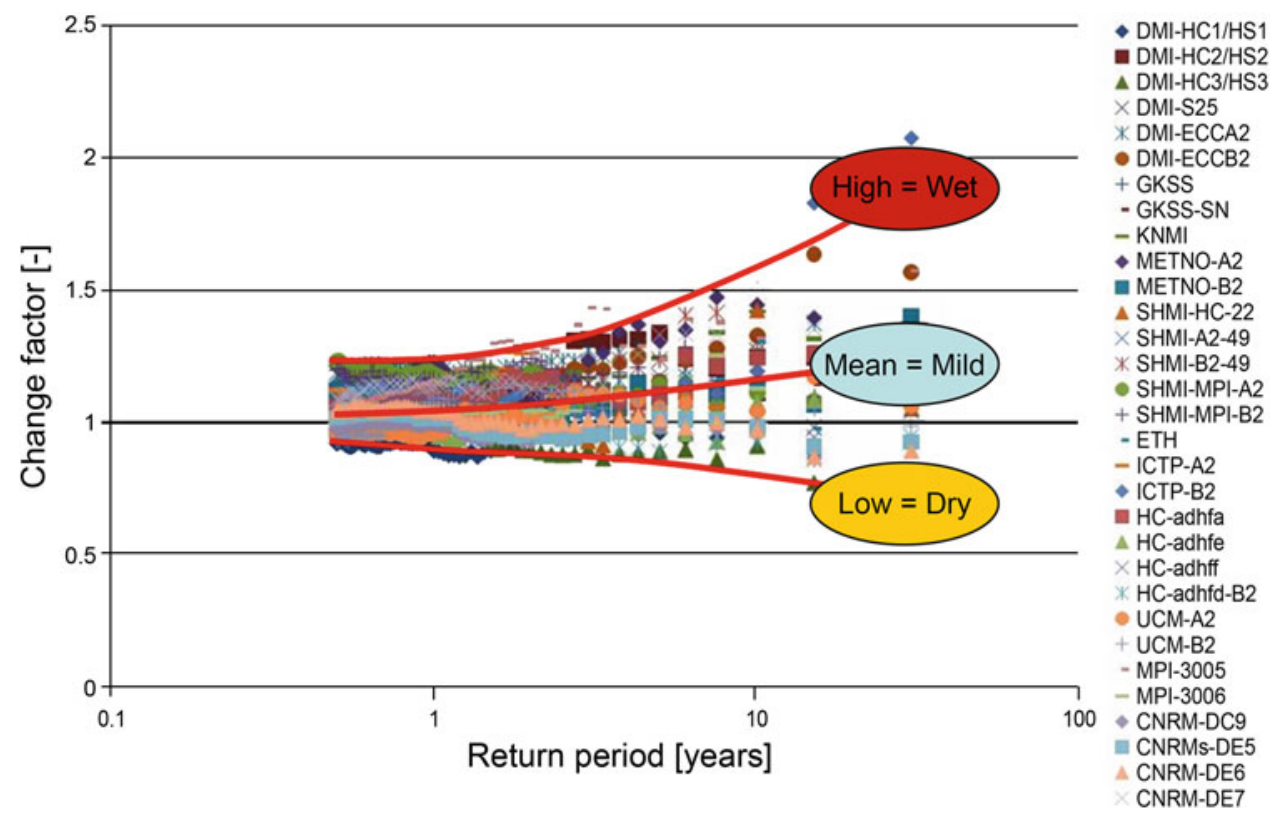

Fig. 7.2 Tailored climate scenarios: hydrological impact based (left CCI-HYDR, Ntegeka et al. 2014) versus meteorological based (right KNMI'06, van den Hurk et al. 2006)

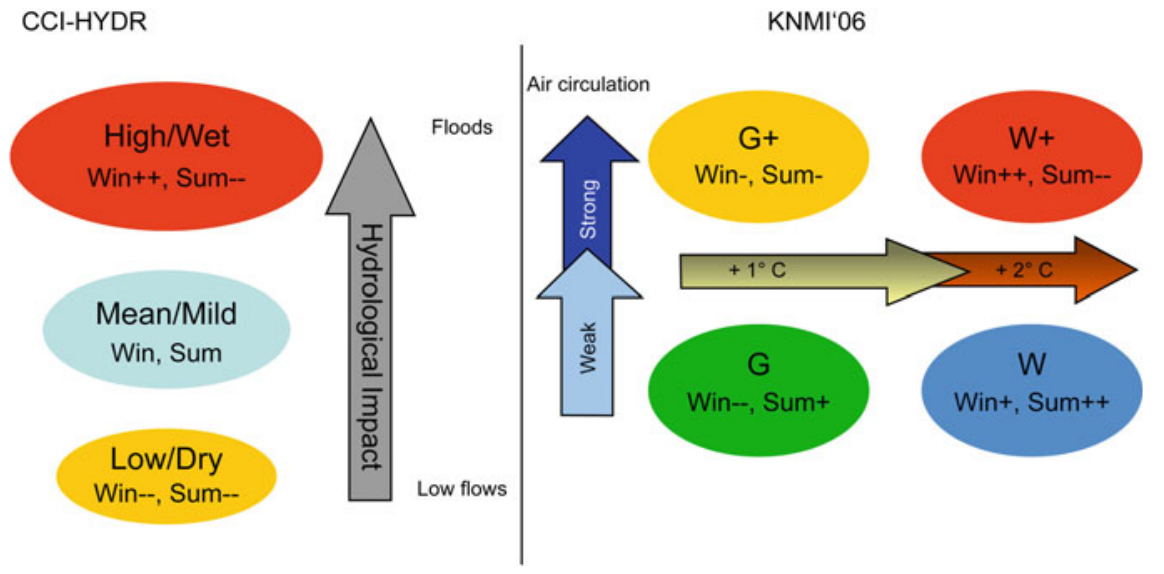

(e.g. Kundzewicz et al. 2006; Hanson et al. 2007) and to longer dry periods (e.g. Good et al. 2006; May 2008), and consequent changes in river flows, as is shown in Table 7.1 based on a review by the European Environment Agency (EEA 2012) and the Intergovernmental Panel on Climate Change in its Fifth Assessment (IPCC 2014). The projections indicate an intensification of rainfall during both winter and summer, but for summer, although the heavy rainfall events may become more intense the intensity of the light and moderate events will decrease. How these meteorological changes will affect river flow shows strong seasonal and regional differences. For north-western Europe, the intensity and frequency of winter and spring river floods are generally expected to increase (EEA 2012).

Based on climate projections from three GCMs and impact analysis in three relatively coarse resolution global hydrological models, Prudhomme et al. (2012) found that river flow in north-western Europe (e.g. Great Britain) would increase in winter with concurrent increases in regional high flow anomalies, and would decrease in summer. Giving particular attention to daily peak flow and related flood risk, Hirabayashi et al. (2013), Arnell and Gosling (2016) and Dankers et al. (2014) found strong sub-regional variations in Europe with both increases (mostly for the UK, France and Ireland) and decreases in the size of the flood-prone populations. Giving particular attention to hydrological droughts, Prudhomme et al. (2014) found significant increases in the frequency of droughts of more than $20 \%$ in central and western Europe. Also based on a coarse-scale hydrological model, but this time with a focus on the main rivers in Europe, Feyen and Dankers (2009) found stream flow droughts will become more severe and persistent in most parts of Europe by the end of the century, except in the most northern and-north eastern regions.

However, it should be noted that these results are based on only one RCM run (HIRHAM 12-km resolution model; 
Table 7.1 Typical change in inland river flows for northern and north-western Europe (EEA 2012; IPCC 2014)

\begin{tabular}{|c|c|c|c|c|}
\hline \multirow[t]{2}{*}{ Variable } & \multicolumn{2}{|c|}{ Northern Europe } & \multicolumn{2}{|c|}{ North-Western Europe } \\
\hline & Observed & Projected & Observed & Projected \\
\hline River flow & + & + & $(+)$ & + \\
\hline River flood & & \pm & + & + \\
\hline River low flow (drought) & 0 & + & 0 & - \\
\hline
\end{tabular}

A2 and A1B SRES scenarios). Based on the same RCM runs and the same hydrological model, Dankers and Feyen (2008) and Rojas et al. (2011) focused on the flood hazard climate change impact and found that extreme discharge levels may increase in magnitude and frequency in parts of western and eastern Europe. In several rivers, the return period of what is currently a 100-year flood may decrease to 50 years or less. Rojas et al. (2012) extended the analysis by applying the same hydrological model to $12 \mathrm{RCM}$ runs, and concluded that results show large discrepancies in the magnitude of change in the 100-year flood for the different RCM runs. Some regions even show an opposite signal of change, but for many regions the projected changes are not statistically significant due to the low signal-to-noise ratio. Western Europe and the British Isles show a robust increase in future flood hazard, mainly due to a pronounced increase in extreme rainfall. A decrease in the 100-year flood, on the other hand, is projected in southern Sweden because the signal is dominated by a strong reduction in snowmeltinduced spring floods, which offsets the increase in average and extreme precipitation. This is also valid for other snowmelt dominated areas of the North Sea region.

Another Europe-wide hydrological impact study was undertaken by Schneider et al. (2013) who applied the global hydrological model WaterGAP3 on a $50^{\prime} \times 50^{\prime}$ European grid. Climate change impacts were based on three GCMs after bias correction. Looking at their results for the North Sea region, they found that flow magnitude was more affected in the northern parts of the North Sea region, such as Sweden and Norway, with strong increases projected in winter precipitation. The lowest impacts across Europe were found in western Europe (i.e. the UK, Ireland, Benelux, Denmark, Galicia and France). The difference is due to the additional impact of temperature on snow cover in the northern region. The greatest impact on peak flows in Scandinavia occurred in April, rather than May, one month earlier in the future. Earlier snowmelt in spring and sporadic melt events in winter will reduce snow storage. However, in Sweden and Norway, these effects were more than compensated for by higher precipitation. During summer (June to September), increased precipitation is offset by greater evapotranspiration. Scandinavia is the only region in Europe where elevated low flows are projected.

\subsubsection{Sub-region or Country-Scale}

\subsubsection{Belgium}

Using finer scale hydrological models (c.f. Sect. 7.3.1), more local European climate studies have projected similar climate change impacts. For 67 catchments in the Scheldt river basin in Flanders, Boukhris et al. (2008) found that extreme peak flows in rivers may increase or decrease depending on the climate scenario used. Winter rainfall volumes increase but evapotranspiration volumes also increase. Depending on the balance between rainfall increase versus evapotranspiration increase, the change in net runoff may switch from positive to negative. From a set of 31 statistically downscaled RCM simulations and more than 20 GCM simulations available for Belgium, the most negative change led to an increase in the river peak flows of about $30 \%$ for the 2080 s (Fig. 7.3).

Impacts on river low flows were more uniform. All of the climate model simulations projected a decrease in river low flow extremes during summer. For Belgian rivers, the change in low flow extremes projected for the 2080s ranged between -20 and $-70 \%$ (Fig. 7.3). The drier summer conditions for Belgium lead to lower groundwater levels, as shown by Brouyére et al. (2004) and Goderniaux et al. (2009) for the Geer catchment, and by Dams et al. (2012) and Vansteenkiste et al. $(2013,2014)$ for the Nete catchment.

\subsubsection{Northern France}

Within the main river basins in France, Boé et al. (2009) found a decrease in mean discharge for summer and autumn. They also simulated a decrease in soil moisture, and a decrease in snow cover, which was especially pronounced at low and middle altitudes. The low flows in France become more frequent. This was also found by Habets et al. (2013) for the rivers Seine and Somme in northern France, based on seven hydrological models ranging from lumped rainfall-runoff to distributed hydrogeological models, and three downscaling methods. A general decrease in river flow of at least $14 \%$ occurred at the outlets of the Seine and Somme basins by the 2050 s and at least $22 \%$ by the 2080 s. More than $90 \%$ of projections showed a decrease in summer flow at these outlets. For the winter high flows, about 
Fig. 7.3 Percentage change in low flows for a low/dry CCI-HYDR climate scenario (upper) and peak flows for a high/wet CCI-HYDR climate scenario (lower), averaged for return periods of $1-30$ years, for 2071-2100 and 67 catchments in Flanders, Belgium (Boukhris et al. 2008)

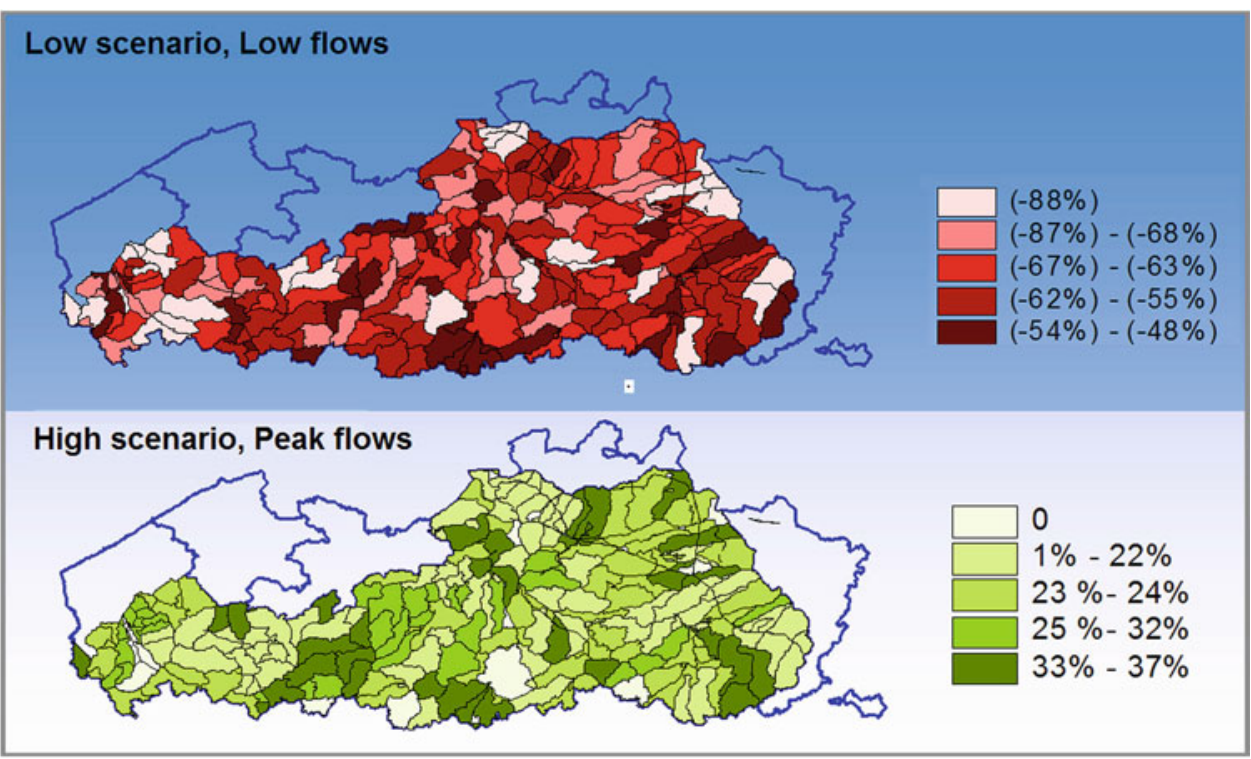

$10 \%$ of projections showed the possibility of increased flow in winter in the River Seine and throughout the year in the River Somme, while $10 \%$ projected a decrease of more than $40 \%$ in river discharge at the basin outlets. For the same basins, Ducharne et al. (2011) found little change in the risk of floods for the 10- and 100-year return periods.

\subsubsection{Germany}

For various river basins in Germany, including the Ems, Weser, Elbe and Rhine (up to the Rees gauge station), based on two RCM simulations Huang et al. (2013) found an increase of about 10-20\% in the 50-year flood levels in the rivers Weser, Rhine, Main, Saale and Elbe. The Ems showed no clear increase and the Neckar a $20 \%$ decrease. In contrast, the Wettreg statistical downscaling method projected a decrease in flood level for the Ems and Weser (10\%), and Saale $(20 \%)$ river basins, and no distinct change for the Main and Neckar. For the River Rhine, Shabalova et al. (2003) found future climate scenarios to result in higher mean discharges in winter (about $+30 \%$ by the end of the century), but lower mean discharges in summer (about $-30 \%$ ), particularly in August (about $-50 \%$ ). Temporal variability in the 10-day discharge increased significantly, even if temporal variability in the climatic inputs remains unchanged. The annual maximum discharge increases in magnitude throughout the Rhine and tends to occur more frequently in winter, suggesting an increasing risk of winter floods. At the Netherlands-German border, the magnitude of the 20-year maximum discharge event increased by 14-29\%; the present-day 20-year event tends to reappear every 3 to 5 years. The frequency of low and very low flows increases, in both scenarios alike. Studying changes in 10-day precipitation sums for return periods in the range 10 to 1000 years in the Rhine basin (within the scope of the RheinBlick2050 project), van Pelt et al. (2012) found changes of up to about +30\%. Pfister et al. (2004) projected increased flooding probably due to higher winter rainfall for the Rhine and Meuse river basins. Most hydrological simulations suggest a progressive shift of the Rhine from a 'rain-fed/meltwater' river to a mainly 'rain-fed' river. Studying projected change in the 1250-year peak flows in the Rhine and Meuse rivers, which are used as the basis for dike design along these rivers, de Wit et al. (2007) found the 1250-year peak flow to increase from 16000 to $18000 \mathrm{~m}^{3} \mathrm{~s}^{-1}$ by 2100 for the Rhine and from 3800 to $4600 \mathrm{~m}^{3} \mathrm{~s}^{-1}$ for the Meuse. For low flow, they found stronger seasonality in the discharge regime of the Meuse: increased low discharge in winter and decreased low discharge in summer. The same findings were obtained by van Huijgevoort et al. (2014).

\subsubsection{Ireland}

For catchments in Ireland, Bastola et al. (2011) simulated monthly changes derived from 17 GCM runs to the input of four hydrological models, and quantified the impact on flood quantiles up to 100-year return periods. They also studied the sensitivity of the impact results within and between hydrological models. The results show a considerable residual risk associated with allowances of $+20 \%$ when uncertainties are accounted for and that the risk of exceeding design allowances is greatest for more extreme, low frequency events (Fig. 7.4) with major implications for critical infrastructure such as culverts, bridges, and flood defences.

\subsubsection{Scandinavia}

In the Scandinavian countries, the increase in peak flows is higher than in other North Sea countries due to the higher 


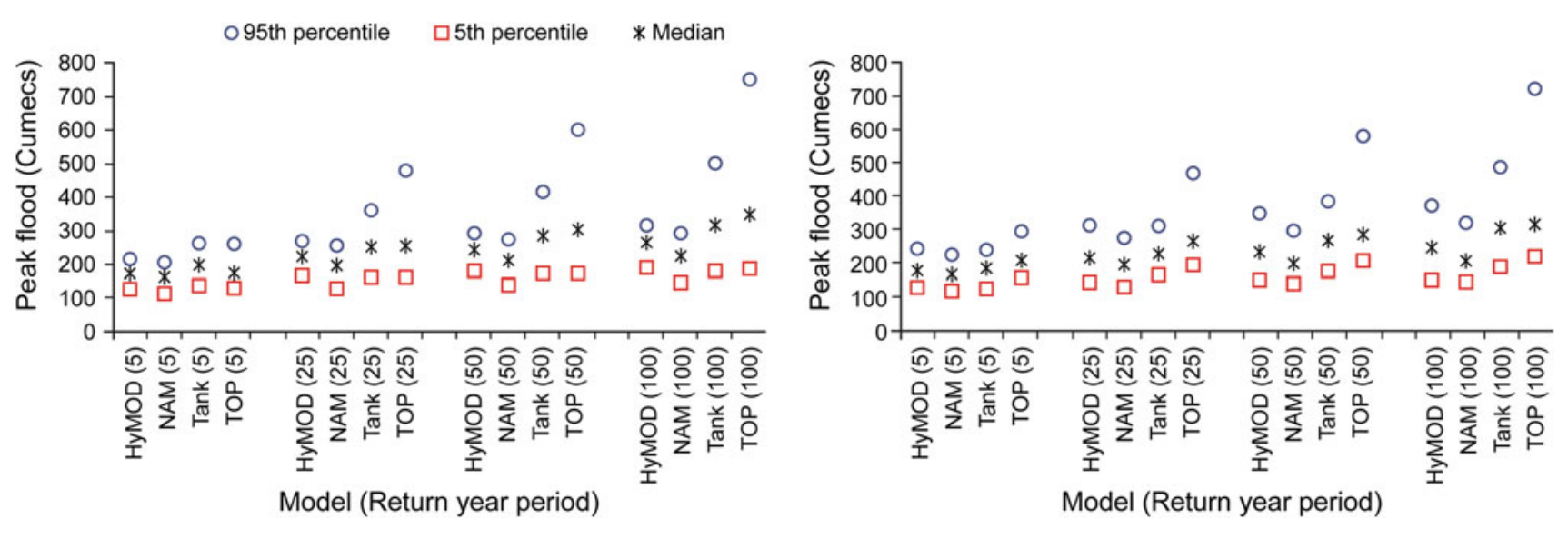

Fig. 7.4 The 95th percentile, 5th percentile and median value for modelled flood quantiles (5-, 25-, 50- and 100-year return periods) for the Moy river basin (left) and Boyne river basin (right) in Ireland (Bastola et al. 2011)

increase in winter rainfall. In Norway, Lawrence and Hisdal (2011) studied the changes in flood discharges for 115 unregulated catchments. Projected changes in peak flow quantiles for return periods of 200, 500 and 1000 years show strong regional differences (Fig. 7.5). These regional differences are explained by the role of snowmelt versus rainfall and how they increase the peak flows. This is, however, different for catchments where peak flows are mainly due to snow melt in spring. In this case, increased winter temperature will cause reduced snow storage, and thus decreased peak flows. An exception is catchments at higher elevations in areas where winter precipitation continues to fall predominantly as snow and higher spring temperatures produce more rapid snowmelt (SAWA 2012). In addition to changes in snowmelt-induced peak flows, the timing of the peak flows becomes earlier (i.e. spring rather than summer). Changes in the seasonality of peak flows occurs in catchments where flows driven by snowmelt decrease but flows driven by winter and autumn rainfall increase. The median projected change in the ensemble of hydrological projections for Norway at 2071-2100 varied from +10 to $+70 \%$ in catchments located in western and south-western regions (Vestlandet), coastal regions of southern and south-eastern Norway (Sørlandet and Østlandet) and in Nordland, and decreased down to $-30 \%$ for northernmost areas (Finnmark and parts of Troms) and middle and southern inland areas (Hedmark, Oppland, and parts of Buskerud, Telemark and Trøndelag).

Similar results to eastern Norway were obtained by Andréasson et al. (2011) for Sweden; see the regional differences in 100-year peak flows in Fig. 7.6. They are based on spatial interpolation, without taking into account the influence of river regulation effects. The northern catchments in Sweden mostly show decreasing peak flows towards the end of the century, whereas the southern basins show increasing 100-year flows. The changes in peak flows vary

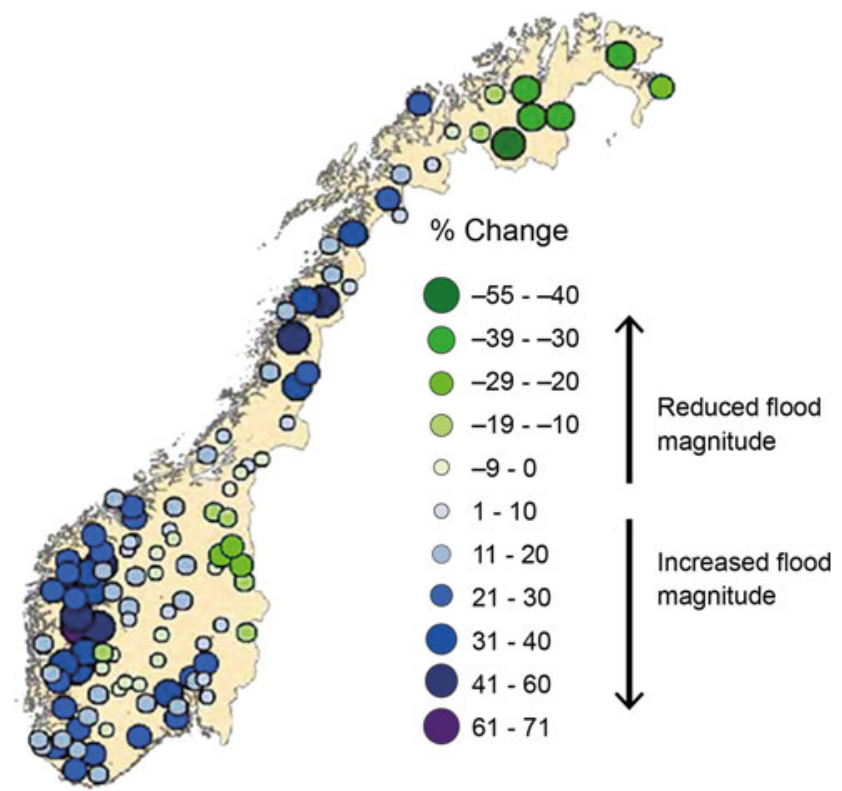

Fig. 7.5 Median projected change in peak flows for 200-year return period and 2071-2100 for 115 unregulated catchments across Norway (Lawrence and Hisdal 2011; SAWA 2012)

from -45 to $+45 \%$. A similar range was found by Teutschbein et al. (2011) and Teutschbein and Seibert (2012) for five catchments in Sweden.

Andersen et al. (2006) studied the climate change impact for six sub-catchments within and for the entire Gjern river basin in Denmark, but only based on one RCM simulation. Mean annual runoff from the river basin increased by $7.5 \%$, whereas greater changes were found for the extremes. The modelled change in the seasonal hydrological pattern is most pronounced in first- or second-order streams draining loamy catchments, which currently have a low base-flow during summer. Reductions of $40-70 \%$ in summer runoff are projected for this stream type. Similar conclusions were obtained 


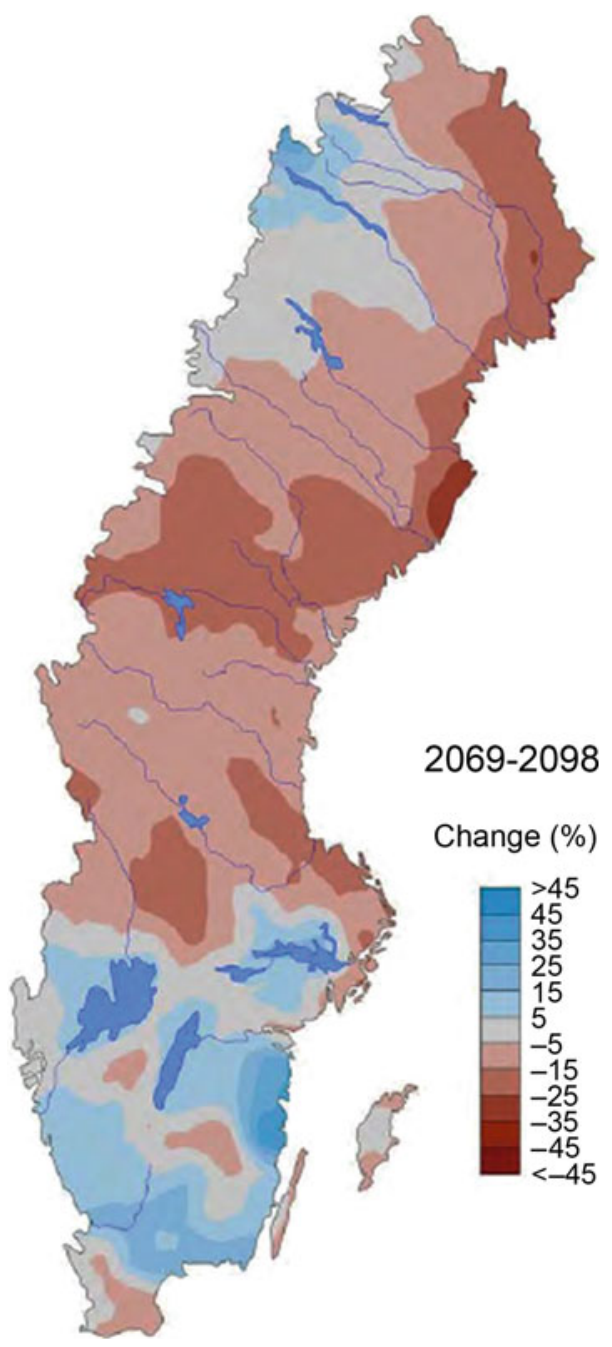

Fig. 7.6 Median projected change in spatially interpolated peak flows for 100-year return period and 2069-2098 for Sweden (Andréasson et al. 2011; SAWA 2012)

based on the same RCM run for five major Danish rivers divided into 29 sub-catchments by Thodsen (2007). The river discharge that exceeded $0.1 \%$ of all days increases approximately $15 \%$, and the 100-year flood is modelled to increase $11 \%$ on average. Andersen et al. (2006) also studied the climate change impact on diffuse nutrient losses (i.e. losses from land to surface waters). Simulated changes in annual mean total nitrogen load were about $+8 \%$. Even though an increase in nitrogen retention in the river system of about $4 \%$ was simulated in the scenario period, an increased in-stream total nitrogen export occurred due to the simulated increase in diffuse nitrogen transfer from land to surface water.

\subsubsection{UK}

For eight catchments in northwest England, Fowler and Kilsby (2007) used an ensemble set of simulation results with the HadRM3H RCM (UKCIP02 scenarios) and undertook a comprehensive treatment of climate modelling uncertainty. They concluded that annual runoff is projected to increase slightly at high elevation catchments, but to reduce by $\sim 16 \%$ for the 2080 s at lower elevations. Impacts on monthly flow distribution are significant, with summer reductions of $40-80 \%$ of mean flow, and winter increases of up to $20 \%$. The changing seasonality has a large impact on low flows, with $95 \%$-percentile flows projected to decrease in magnitude by $40-80 \%$ in summer months (Fig. 7.7). In contrast, high flows ( $>5 \%$-percentile flows) are projected to increase in magnitude by up to $25 \%$, particularly at high elevation catchments, providing an increased risk of flooding during winter. Based on the same RCM and with a focus on river flood hazards in winter, Kay et al. (2006) found increased flood hazard particularly in East Anglia and the Upper Thames, with flood peaks in some places increasing by more than $50 \%$ for the 50-year return level. Clear regional differences were also found by Arnell (2011) and Christierson et al. (2012) after analysing many UK catchments and several climate models or scenarios. Based on six catchments across the UK, Arnell (2011) found clear differences between northern and southern catchments, with large climate change effects in winter in the north and summer in the south. After analysing 70 UK catchments, Christierson et al. (2012) found major differences between the western and northern mountainous part of the UK and the rest of the UK, with an increase in winter river flow over the western part but less clear results or a decrease in mean monthly river flows all year round. In summer, most catchments showed negative or very slightly positive changes, with the largest flow decrease in the Thames, Anglian and Severn river basin districts, with decreases of $10 \%$ or more in mean monthly flows all year round and even more in summer.

A specific study for the River Thames by Diaz-Nieto and Wilby (2005) concluded that substantial reductions in summer precipitation accompanied by increased potential evaporation throughout the year, lead to reduced river flow in late summer and autumn. Kay et al. (2006) found the same situation even in winter for some catchments in the south and east of England despite an increase in extreme rainfall events. This was explained by higher soil moisture deficits in summer and autumn that may have an influence up to the start of winter. Also for the Thames basin, but based on the more recent UKCP09 scenarios, Bell et al. (2012) found a $10-15 \%$ increase in winter rainfall by the end of the century. This might potentially lead to higher flows than the River Thames can accommodate. Towards the downstream end, they estimated an average change in modelled 20-year return period flood peaks by the 2080 s of $36 \%$ (range -11 to $+68 \%)$.

For the River Avon catchment, Smith et al. (2014) obtained changes in the 25 -year return period flows of +15 , 
Fig. 7.7 Change in $95 \%$ percentile flow between the HadRM3H control and future scenarios for 2020s, 2050s and 2080s time-slices. The uncertainty bounds are for the different SRES scenarios (Fowler and Kilsby 2007)

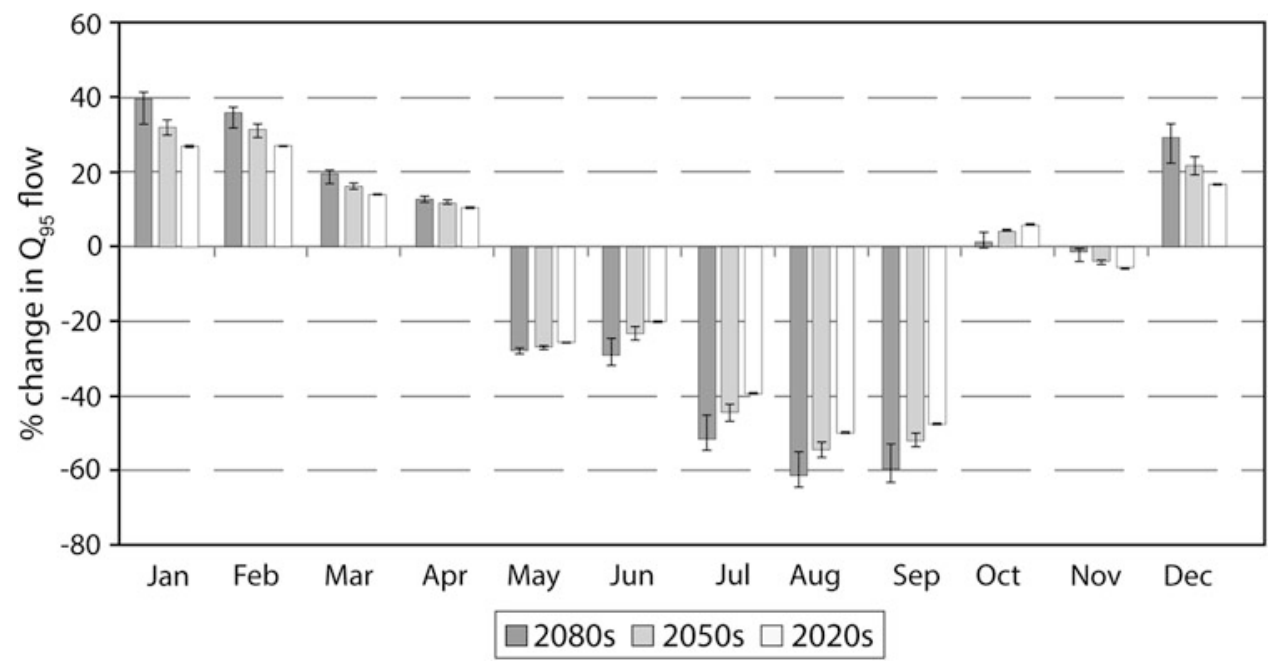

+2 or $+7 \%$ based on three different methods for transferring the climate model output to hydrological model input. For 200-year peak flows, these percentages increased to $+22+19$ and $+6 \%$. For the River Medway catchment, Cloke et al. (2010) found a significant lowering of summer flow with a more than $50 \%$ reduction for $2050-2080$ and up to $70 \%$ in some months. For six other UK catchments, Arnell (2011) simulated changes in summer runoff of between -40 and $+20 \%$.

In terms of groundwater recharge, Herrera-Pantoja and Hiscock (2008) concluded that by the end of the century decreases in recharge of between 7 and $40 \%$ are expected across the UK, leading to increased stress on local and regional groundwater supplies that are already under pressure to maintain both human and ecosystem needs.

The impacts that these hydrological changes may have in terms of flood and water availability risk were assessed by the UK-Government funded initiative AVOID (Warren et al.
2010; MetOffice 2011). Based on an ensemble set of 21 GCMs, it is shown that nearly three-quarters of the models project an increase in flood risk. For the 2030s and averaged over the UK as a whole, the change ranges from -20 to $+70 \%$, with a mean of $+4 \%$ (Fig. 7.8). Larger increases are shown for longer time horizons. Overall, the models show a tendency for a large increase in flood risk for the UK as a whole.

The water availability threat in the UK (calculated using the Human Water Security Threat indicator by Vörösmarty et al. 2010) ranges from very high in the south-east to moderate in the south, Midlands, and southern Scotland (Fig. 7.9). For southern England, the loss in deployable water output due to climate change and population growth is estimated to be $3 \%$ by 2035 (Charlton and Arnell 2011). Increased irrigation requirements were also found for the south-east and north-west of England (Henriques et al. 2008).
Fig. 7.8 Change in average annual flood risk for the UK, based on 21 GCMs under two emission scenarios (A1B and A1B-2016-5-L), for four time horizons (MetOffice 2011). The plots show the 25th, 50th, and 75 th percentiles (represented by the boxes), and the maximum and minimum values (shown by the extent of the whiskers)

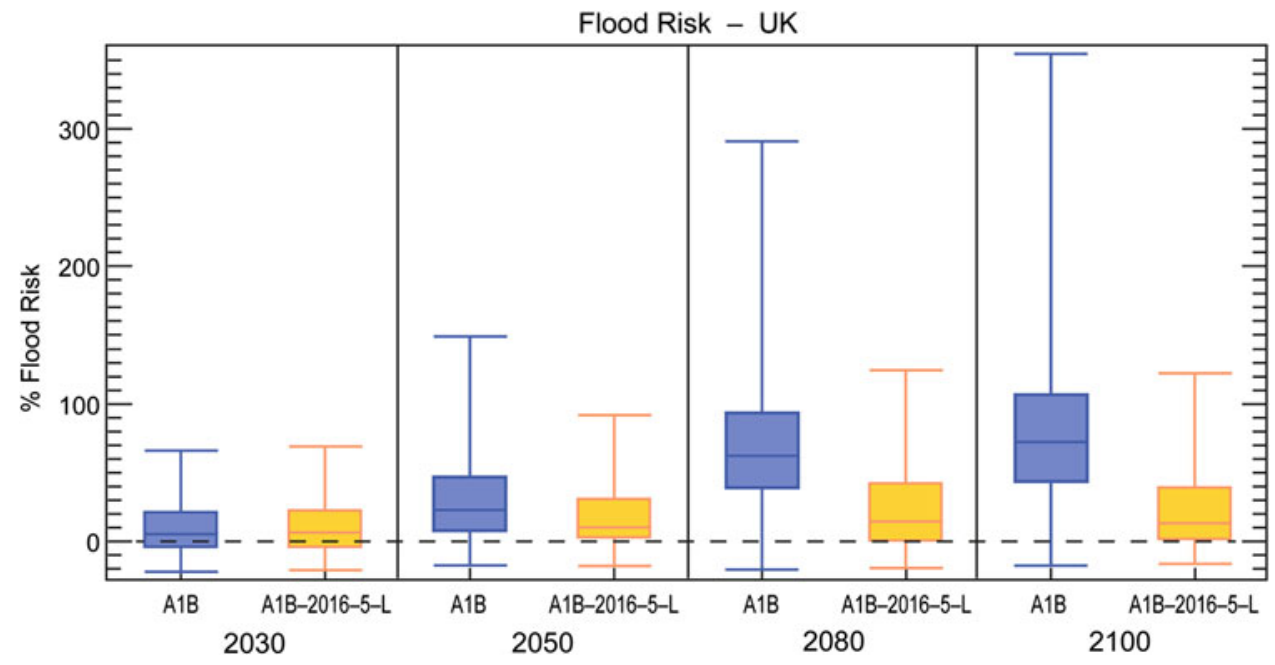


Fig. 7.9 The human water security threat for the UK (MetOffice 2011)

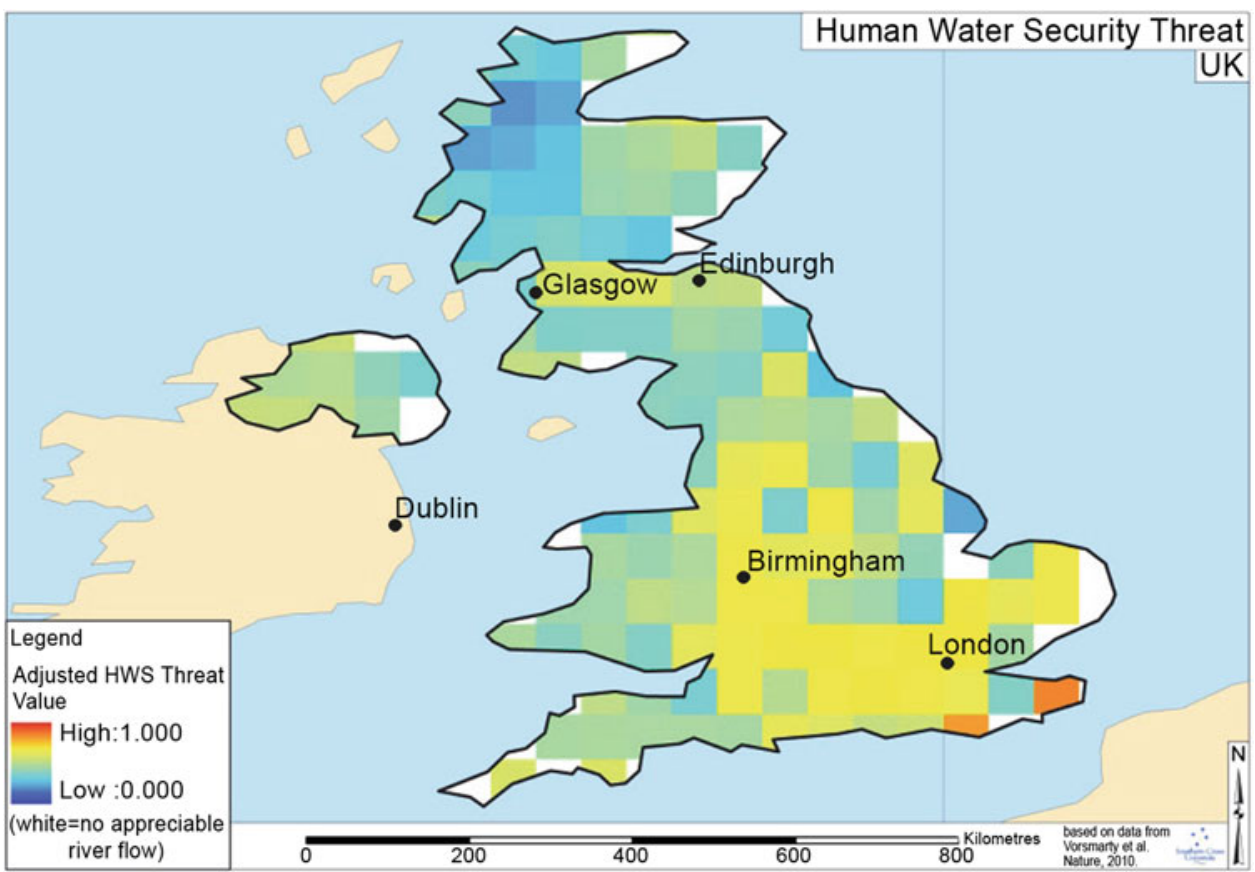

\subsubsection{Comment on Low Flows}

Although models project that climate change will cause a decrease in low flows in north-western European rivers over the coming decades, it should be noted that most models have low accuracy in the simulation of low flow extremes. Evidence for this is provided by Gudmundsson et al. (2012b) based on nine large-scale hydrological models after comparison to observed runoff from 426 small catchments across Europe. Further evidence is provided by Vansteenkiste et al. $(2013,2014)$ for a catchment in Belgium. Low accuracy for low flows is associated with the representation of hydrological processes, such as the depletion of soil moisture stores (Vansteenkiste et al. 2013, 2014).

\subsubsection{Estuaries}

In addition to changes in inland rainfall, temperature and reference evapotranspiration, which lead to changes at the upstream boundaries of estuaries, it is also important to consider changes in the downstream coastal boundary. In relation to the Scheldt estuary (Fig. 7.10), Ntegeka et al. (2011, 2012) studied projected changes in mean sea level, storm surge levels, wind speed and wind direction, and their correlation with changes in inland rainfall (see also Monbaliu et al. 2014 and Weisse et al. 2014). The changes in storm surge levels were derived from changes in sea-level pressure (SLP) in the Baltic Sea, the Atlantic Ocean area west of France, and the Azores, and a correlation model between SLP and storm surge level. The model was derived after analysing SLP composite maps and SLP-surge correlation maps (Fig. 7.11) for days where the surge exceeds given thresholds (for different return periods). Correlations were identified between the inland (rainfall, runoff) and coastal climatic changes. Based on the ensemble set of change factors, tailored climate scenarios (tailored for the specific application of flood impact analysis along the Scheldt) were developed to the 2080s. After statistical analysis, a reduced set of climate scenarios ('high', 'mean' and 'low') was derived for each boundary condition (runoff upstream, mean sea level, and surge downstream). Smart combinations of the scenarios account for the correlation between boundary changes (Monbaliu et al. 2014; Weisse et al. 2014).

\subsubsection{Overview}

Table 7.2 summarises the hydrological impact studies reviewed in this assessment. Because many of the studies report climate change impacts on peak river flows, the impacts were reported as percentage change by the end of the century. Many other hydrological variables are also of relevance, such as mean or low flows, but fewer studies report percentage change in these variables or the various study results are not directly comparable (e.g. derived at different time scales: annual vs. seasonal or monthly). It should also be noted that in several regions, the sign and order of magnitude of change are not consistent when results from different studies are compared. This reflects differences in methodology (number and type of climate model and greenhouse gas scenario, type of hydrological-hydraulic impact model, and statistical downscaling and analysis approach; see the Supplement S7 for more discussion on such issues), as well as uncertainties in the numerical projections of changes in hydrology. That results on changes in 
Fig. 7.10 Case study on the Scheldt Estuary: boundary conditions are the downstream surge (North Sea) and the upstream river flows (different rivers) for which correlation in the changes needs to be taken into account (Ntegeka et al. 2012)

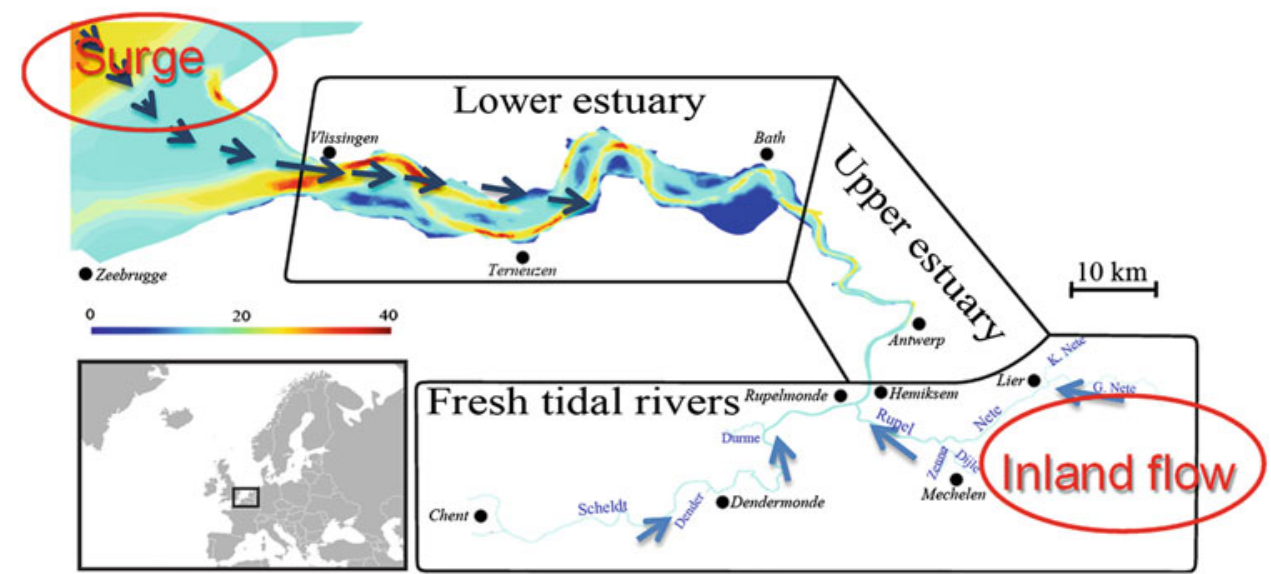

A recent review by Willems et al. (2012a, b) and Arnbjerg-Nielsen et al. (2013) of the impacts of climate change on short-duration rainfall extremes and urban drainage showed that short-duration rainfall extremes were projected to increase by $10-60 \%$ in 2100 relative to the baseline period (1961-1990). An urban drainage system may damp or amplify changes in precipitation, depending on the system characteristics. For the sewer network of Lund, Sweden, Niemczynowicz (1989) found the relative change in urban runoff volume to be higher than for the rainfall input. They found that a $30 \%$ increase in the 40-min rainfall intensity would lead to a 66-78\% increase in sewer overflow volume (depending on a return period of between 1 and 10 years and the type of design storm). In Sweden, Olsson et al. (2009) found an increase in the number of urban drainage system surface floods of $20-45 \%$ for Kalmar in 2100. For Odense in Denmark, Mark et al. (2008) found flood depth and the number of buildings currently affected once in every 50 years would correspond to a return period of 10 years in the future (based on the impacts discussed by Larsen et al. 2009 and Arnbjerg-Nielsen 2012). For Roskilde, also in Denmark, Arnbjerg-Nielsen and Fleischer (2009) found that a $40 \%$ increase in design rainfall intensities would lead to a factor of 10 increase in the current level of damage costs related to sewer flooding. The actual change in cost will depend on catchment characteristics. In a similar study for another location with the same increase in rainfall intensity, Zhou et al. (2012) reported a factor 2.5 increase in annual costs. A common conclusion, however, is that the main impact of an increase in precipitation extremes is not primarily related to the additional cost associated with the most extreme events, but rather with the damage occurring far more frequently.

A higher factor increase in sewer impacts compared to the factor increase in rainfall was also reported by Nie et al. (2009) for Fredrikstad, Norway. They concluded that the total volume of water spilling from overflowing manholes is
Hydrological analyses of urban catchments are based on studies with a particular focus on fine-scale meteorological and hydrological processes (as explained in Sect. 7.2.2). 
Table 7.2 Summary of impact results on river flows available for the North Sea region

\begin{tabular}{|c|c|c|c|c|c|}
\hline Region & Source & GCM-RCM(s) considered & $\begin{array}{l}\text { Greenhouse gas } \\
\text { scenario(s) }\end{array}$ & $\begin{array}{l}\text { Hydrological-hydraulic } \\
\text { impact model(s) }\end{array}$ & $\begin{array}{l}\text { Change in river } \\
\text { peak flow by } 2100\end{array}$ \\
\hline Belgium & $\begin{array}{l}\text { Boukhris et al. (2008), } \\
\text { Ntegeka et al. (2014); } \\
\text { Vansteenkiste et al. (2013, 2014), } \\
\text { Tavakoli et al. (2014) }\end{array}$ & $\begin{array}{l}31 \text { PRUDENCE RCM } \\
\text { runs, } 18 \\
\text { ENSEMBLES RCM runs }\end{array}$ & $\begin{array}{l}\text { SRES A1, A1B, A2, } \\
\text { B1, B2 }\end{array}$ & $\begin{array}{l}\text { Lumped conceptual NAM, PDM, } \\
\text { VHM spatially distributed } \\
\text { MIKE-SHE, WetSpa }\end{array}$ & Up to $+30 \%$ \\
\hline Denmark & $\begin{array}{l}\text { Andersen et al. (2006), } \\
\text { Thodsen (2007) }\end{array}$ & $\begin{array}{l}\text { HIRHAM RCM nested in } \\
\text { ECHAM4/OPYC GCM }\end{array}$ & SRES A2 & $\begin{array}{l}\text { NAM rainfall runoff model /Mike } \\
\text { 11-TRANS modelling system }\end{array}$ & Up to $12.3 \%$ \\
\hline France & $\begin{array}{l}\text { Boé et al. (2009), } \\
\text { Habets et al. (2013), } \\
\text { Ducharne et al. (2011) }\end{array}$ & 6 IPCC AR4 GCM runs & SRES A1B and A2 & $\begin{array}{l}\text { Hydrological models MARTHE, } \\
\text { MODCOU, SIM, CLSM, EROS, } \\
\text { GARDENIA and GR4 for Seine } \\
\text { and Somme }\end{array}$ & $\begin{array}{l}\text { No significant } \\
\text { change }\end{array}$ \\
\hline Germany & Huang et al. (2013) & REMO \& CCLM RCMs & SRES A1B, A2, B1 & SWIM eco-hydrological model & -20 to $+20 \%$ \\
\hline $\begin{array}{l}\text { Germany- } \\
\text { Netherlands }\end{array}$ & van Pelt et al. (2012) & $\begin{array}{l}5 \text { RCMs mainly } \\
\text { ENSEMBLES + } 13 \\
\text { CMIP3 GCMs }\end{array}$ & SRES A1B & HBV model Rhine basin & \\
\hline Ireland & Bastola et al. (2011) & 17 GCMs AR4 & SRES A1B, A2, B1 & $\begin{array}{l}4 \text { conceptual models (HyMOD, } \\
\text { NAM, TANK, TOPMODEL) for } 4 \\
\text { catchments }\end{array}$ & Most up to $+20 \%$ \\
\hline \multirow[t]{3}{*}{ Netherlands } & $\begin{array}{l}\text { Shabalova et al. (2003), Lenderink } \\
\text { et al. } 2007\end{array}$ & $\begin{array}{l}\text { HadRM2 and HadRM3H } \\
\text { RCMs }\end{array}$ & $\begin{array}{l}\text { SRES A2 (for } \\
\text { Lenderink et al. 2007) }\end{array}$ & $\begin{array}{l}\text { RhineFlow distributed } \\
\text { hydrological model }\end{array}$ & Up to $+30 \%$ \\
\hline & de Wit et al. (2007) & KNMI'06 scenarios & & $\begin{array}{l}\text { Rhineflow and Meuseflow } \\
\text { distributed hydrological models }\end{array}$ & \\
\hline & Leander et al. (2008) & 3 PRUDENCE RCMs & SRES A2 & HBV model Meuse basin & \\
\hline Norway & Lawrence and Hisdal (2011) & $\begin{array}{l}13 \text { RCM runs RegClim \& } \\
\text { ENSEMBLES }\end{array}$ & SRES A1B, A2, B2 & $\begin{array}{l}\text { HBV rainfall runoff model } \\
\text { 'Nordic' version }\end{array}$ & -30 to $+70 \%$ \\
\hline Sweden & $\begin{array}{l}\text { Andréasson et al. (2011), } \\
\text { Teutschbein et al. (2011), } \\
\text { Teutschbein and Seibert (2012) }\end{array}$ & $\begin{array}{l}12 \text { RCM runs SMHI \& } \\
\text { ENSEMBLES }\end{array}$ & SRES A1, A2, B1, B2 & HBV rainfall runoff model & -45 to $+45 \%$ \\
\hline \multirow[t]{11}{*}{ UK } & Cameron (2006) & $\begin{array}{l}\text { UKCIP02 climate change } \\
\text { scenarios: HadRM3 RCM } \\
\text { nested in HadCM3 GCM }\end{array}$ & & TOPMODEL & \\
\hline & Kay et al. (2006) & $\begin{array}{l}1 \text { RCM: HadRM3H } \\
\text { (UKCP02) }\end{array}$ & SRES A2 & $\begin{array}{l}\text { Simplified PDM lumped } \\
\text { conceptual rainfall runoff model }\end{array}$ & Some up to $+50 \%$ \\
\hline & Fowler and Kilsby (2007) & $\begin{array}{l}\text { Ensemble of runs for } 1 \\
\text { RCM: HadRM3H } \\
\text { (UKCP02) }\end{array}$ & SRES A2 & ADM model & Up to $+25 \%$ \\
\hline & Chun et al. (2009) & 7 GCMs \& RCMs & & $\begin{array}{l}\text { pd4-2par conceptual rainfall-runoff } \\
\text { model for } 6 \text { catchments }\end{array}$ & \\
\hline & Cloke et al. (2010) & $\begin{array}{l}\text { HadRM3 RCM: subset of } \\
\text { UKCP09 scenarios }\end{array}$ & SRES A1B & $\begin{array}{l}\text { CATCHMOD semi-distributed } \\
\text { conceptual model for Medway } \\
\text { catchment }\end{array}$ & \\
\hline & Arnell (2011) & 21 CMIP3 GCMs & & $\begin{array}{l}\text { Cat-PDM conceptual model for } 6 \\
\text { catchments }\end{array}$ & \\
\hline & Charlton and Arnell (2011) & $\begin{array}{l}\text { UKCP09 climate change } \\
\text { scenarios }\end{array}$ & & $\begin{array}{l}\text { Cat-PDM conceptual model for } 6 \\
\text { catchments }\end{array}$ & \\
\hline & Christierson et al. (2012) & $\begin{array}{l}\text { UKCP09 climate change } \\
\text { scenarios }\end{array}$ & SRES A1B & $\begin{array}{l}\text { PDM lumped conceptual rainfall } \\
\text { runoff model and CATCHMOD } \\
\text { semi-distributed conceptual model } \\
\text { for } 70 \text { catchments }\end{array}$ & \\
\hline & Bell et al. (2012) & $\begin{array}{l}\text { UKCP09 climate change } \\
\text { scenarios }\end{array}$ & SRES A1B & G2G model Thames basin & -11 to $+68 \%$ \\
\hline & Kay and Jones (2012) & $\begin{array}{l}\text { Perturbed parameter } \\
\text { ensemble of } 1 \mathrm{RCM}\end{array}$ & & $\begin{array}{l}\text { Nationwide grid-based runoff and } \\
\text { routing model UK }\end{array}$ & \\
\hline & Smith et al. (2014) & $\begin{array}{l}18 \text { RCMs from } \\
\text { ENSEMBLES and } \\
\text { UKCP09 }\end{array}$ & SRES A1B & $\begin{array}{l}\text { HBV-light lumped conceptual } \\
\text { rainfall runoff model Avon } \\
\text { catchment }\end{array}$ & -1 to $+23 \%$ \\
\hline
\end{tabular}


Table 7.2 (continued)

\begin{tabular}{|c|c|c|c|c|c|}
\hline Region & Source & GCM-RCM(s) considered & $\begin{array}{l}\text { Greenhouse gas } \\
\text { scenario(s) }\end{array}$ & $\begin{array}{l}\text { Hydrological-hydraulic } \\
\text { impact model(s) }\end{array}$ & $\begin{array}{l}\text { Change in river } \\
\text { peak flow by } 2100\end{array}$ \\
\hline $\begin{array}{l}\text { UK and NW } \\
\text { Europe }\end{array}$ & Prudhomme et al. (2012) & $\begin{array}{l}3 \text { GCMs: ECHAM5, } \\
\text { IPSL, CNRM }\end{array}$ & & $\begin{array}{l}\text { Global hydrological models } \\
\text { JULES, MPI-HM, WaterGAP } \\
\text { (WaterMIP project) }\end{array}$ & \\
\hline $\begin{array}{l}\text { Larger rivers } \\
\text { in Europe }\end{array}$ & $\begin{array}{l}\text { Dankers and Feyen (2008), Feyen } \\
\text { and Dankers (2009), Rojas et al. } \\
(2011,2012)\end{array}$ & $\begin{array}{l}\text { HIRHAM5 and } 12 \\
\text { ENSEMBLES RCM runs }\end{array}$ & SRES A2, A1B & $\begin{array}{l}\text { Coarse scale spatially distributed } \\
\text { model LISFLOOD }\end{array}$ & $\begin{array}{l}\text { Dependent on } \\
\text { sub-region }\end{array}$ \\
\hline Europe & Schneider et al. (2013) & $3 \mathrm{GCMs}$ & SRES A2 & $\begin{array}{l}\text { Global hydrological model } \\
\text { WaterGAP3 }\end{array}$ & $\begin{array}{l}\text { Dependent on } \\
\text { sub-region }\end{array}$ \\
\hline \multirow[t]{4}{*}{ Globe } & Arnell and Gosling (2016) & 1 GCM: HadCM3 & SRES A1B & $\begin{array}{l}\text { Water balance model } \\
\text { Mac-PDM. } 09\end{array}$ & $\begin{array}{l}\text { Dependent on } \\
\text { sub-region }\end{array}$ \\
\hline & Dankers et al. (2014) & $5 \mathrm{GCMs}$ & RCP8.5 & $\begin{array}{l}9 \text { global water balance models } \\
\text { (from WaterMIP) }\end{array}$ & $\begin{array}{l}\text { Dependent on } \\
\text { sub-region }\end{array}$ \\
\hline & Prudhomme et al. (2014) & 5 GCMs & $\mathrm{RCP} 2.6,8.5$ & 9 global water balance models & \\
\hline & Hirabayashi et al. (2013) & 11 GCMS & RCPs & $\begin{array}{l}\text { global river routing model with } \\
\text { inundation scheme }\end{array}$ & $\begin{array}{l}\text { Dependent on } \\
\text { sub-region }\end{array}$ \\
\hline
\end{tabular}

two- to four-fold higher than the increase in precipitation, and that the total sewer overflow volume is 1.5 - to three-fold higher. They also found that the number of overflowing manholes and number of surcharging sewers may change dramatically, but the precise magnitude of change in response to the change in precipitation is uncertain.

Willems (2013a) found that for sewer systems in Flanders, Belgium, built for design storms with return periods of two to 20 years, that the present-day design storms would increase for the high-tailored climate scenario by +15 to $+50 \%$ depending on the return period (range 1 month to 10 years) (Fig. 7.12). For the mean-tailored scenario, the changes were less: from +4 to $+15 \%$. For the high scenario, the return period of sewer flooding increases by about a factor 2 .

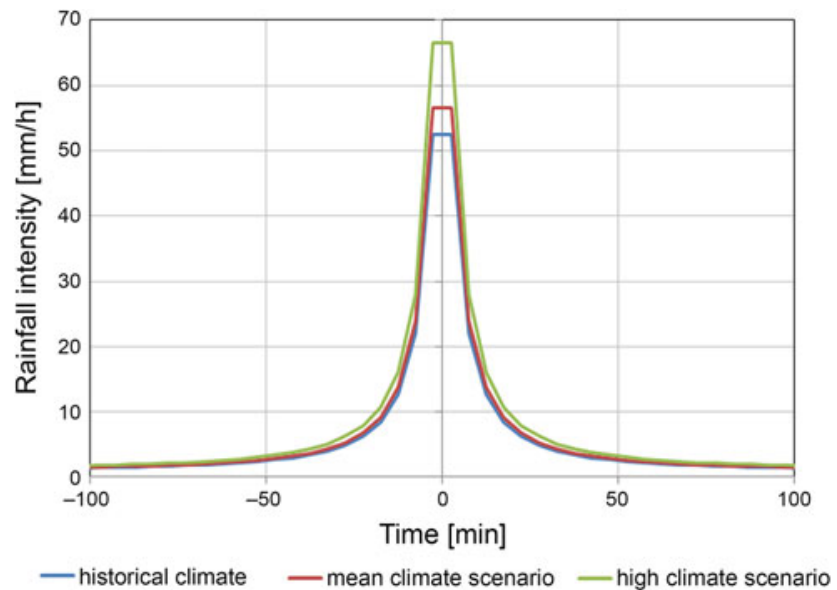

Fig. 7.12 Change in the design storm for sewer systems in Flanders, Belgium, for a 2-year return period for high and mean climate scenarios (Willems 2013a)
For the Windermere drainage area in NW England, Abdellatif et al. (2014) concluded based on the UKCP09 scenarios that an increase in the design storm of as little as $15 \%$ is projected to cause an increase of about $40 \%$ in flood volume due to surface flooding. However, impacts on house basements showed a damping effect (a $35 \%$ increase in design storm leads to $16 \%$ in the number of basements at risk of flooding). This confirms that the precise effects of climate change strongly depend on the type of impacts studies and the specific properties of the sewer system.

The impacts of climate change on sewer flood and overflow frequencies and volumes show wide variation. Studies indicate a range from a four-fold increase to as low as a $5 \%$ increase, depending on the system characteristics (Willems et al. 2012a, b). Floods and overflows occur when runoff or sewer flow thresholds are exceeded. Given that the response of the sewer system to rainfall may be highly non-linear, the changes in the sewer response may be much stronger than the changes in rainfall. And the impact ranges can even by wider when studying the impacts of sewer overflows on receiving rivers. Sewer overflow mainly occurs in summer and as models project the likelihood of lower river flow in summer in north-western Europe, dilution effects in the receiving water might be less, thus increasing impacts on river water quality and aquatic life. Astaraie-Imani et al. (2012) found for a semi-real case study in the UK that changes in rain storm depth and peak rainfall intensity of up to $+30 \%$ by the 2080 s could cause strong deterioration in river water quality; an increase in rain storm depth of $30 \%$ led to an increase in river ammonium concentration of about $40 \%$ and a decrease in dissolved oxygen concentration of about $80 \%$. This was found to correspond with a strong increase in the frequency of breaching given concentration thresholds (i.e. immission standards). The 
frequency of breaching the dissolved oxygen threshold of $4 \mathrm{mg} \mathrm{l}^{-1}$ increased from 49 to $99 \%$; the frequency of exceeding the ammonium threshold of $4 \mathrm{mg} \mathrm{l}^{-1}$ increased from 45 to $79 \%$. The effect of changes in peak rainfall intensity was found to be an order of magnitude lower.

Climate-driven changes in large-scale atmospheric circulation and related wind fields may cause significant changes in the amount and type of sediment on catchment surfaces available for wash-off into urban drainage systems. Higher deposition during prolonged dry periods will increase pollution concentrations in first flushes. This will lead to higher pollution loads in sewer overflows and in inflow to wastewater treatment plants; the latter leading to higher solids loads to clarifiers, different treatment efficiencies and higher pollution loads. Downstream of the treatment plants, receiving rivers during long dry spells in future summers may have reduced capacity to assimilate the more concentrated effluent. Prolonged dilute loading of wastewater treatment plants due to low-intensity long-duration precipitation events can also affect wastewater treatment with potential for major impacts on overall treatment (Plosz et al. 2009).

Changes other than those related to climate may also occur in urban areas and affect or strengthen urban drainage impacts. For example, changes in pavement surfaces, and these should not be seen in isolation but as related to population growth and increase in welfare, and thus partly interrelated with anthropogenic climate change. Semadeni-Davies et al. (2008) analysed the combined impact of climate change and increased urbanisation in Helsingborg, Sweden, and found that this could result in a four-fold increase in sewer overflow volumes. Using a similar approach, Olsson et al. (2010) analysed future loads on the main combined sewer system in Stockholm, Sweden, due to climate change and population increase. They estimated annual total inflow to the treatment plant to increase by $15-20 \%$, sewer overflow volumes to increase by 5-10\% and critically high water levels to increase by $10-20 \%$ in the first half of the century. For the latter half of the century, they found no further increase in total inflow, but a 20-40\% increase in sewer overflow volumes and a 30-40\% increase in high water levels (within the sewer system). Both studies highlighted the importance of addressing climate change impacts in combination with other key non-stationary drivers of equal importance (e.g. urbanisation trends, sewer system or management changes). In fact, the study by SemadeniDavies et al. (2008) clearly showed that climate change is not the most important driver of increased pollution levels, and that increases in damage may be effectively counterbalanced by measures not solely related to urban drainage.

Tait et al. (2008) confirmed that increased urbanisation (related to increased population and economic growth) also had a significant impact on urban runoff. For a typical urban area in the UK, in addition to climate change they assumed that paved areas would increase by about $25 \%$ of their current value and roof areas by about $10 \%$. Model simulations showed that sewer overflow volumes would increase by about $15-20 \%$ when only the increase in paved areas is considered. These changes are comparable to those expected from climate change.

Climatic variability at multi-decadal time scales has been detected by several authors (Stahl et al. 2010, 2012; Hannaford et al. 2012; Boé and Habets 2013; Willems 2013b). This must also be considered, given that it could temporarily limit, reverse or even increase the long-term impacts of climate change (Boé and Habets 2013).

\subsection{Conclusion}

Hydrological extremes are projected to become more intense. These changes are largely driven by changes in precipitation, which RCM rainfall projections for the North Sea region suggest will become significantly more intense (see Chap. 5; Van der Linden and Mitchell 2009). Future winters are expected to see both an increase in the volume and intensity of precipitation. The intensity of summer extremes may also increase albeit with a reduction in overall volume. These findings are consistent with recent observations at some monitoring stations that show winter extremes in high river flow are already increasing (see Chap. 4).

Quantifying future changes in hydrology is difficult. This reflects the high uncertainties in model output: mainly due to uncertainties in the climate processes, and - to a lesser extent - in knowledge of the hydrological processes and their schematisation in hydrological impact models. The impact uncertainties also reflect the level of uncertainties in future greenhouse gas emissions and concentrations.

Taking the uncertainties into account, the reported overview of impact results for rivers in the North Sea region in Table 7.2, indicates increases in river peak flow by 2100 of up to $+30 \%$ for many rivers and even higher for some. An increase in river peak flows is more evident for the northern basins of the North Sea region. The greatest increases are projected for catchments in south-western Norway, up to $+70 \%$ for 200-year peak flows. In snow-dominated catchments of Norway and southern Sweden, earlier spring flooding is projected. These spring floods do not always increase, however, peak flows from snowmelt may decrease when higher spring temperatures lead to reduced snow storage. Decreasing snowmelt-induced spring flow, and increased rain-fed flow in winter and autumn may change the seasonality of peak flows and floods. In northern France and Belgium, an increase in river peak flow is less clear in that not all models project an increase. Hence, the spatial differences mainly occur in a north-south direction. The 
position of a river basin relative to the ocean is also important. Allan et al. (2005) found that the greater the proximity the greater the potential damping of any climate change effect.

The impacts of climate change on sewer flood and overflow frequencies and volumes vary widely. The specific characteristics of an urban drainage system will dictate whether the net result of the projected increase in, for example, short-duration rainfall extremes is to damp or amplify these changes in precipitation. The precise amplitude of response is highly uncertain and non-linear. The combined impact of climate change and increased urbanisation in some parts of the North Sea region could result in as much as a four-fold increase in sewer overflow volumes.

Open Access This chapter is distributed under the terms of the Creative Commons Attribution 4.0 International License (http:// creativecommons.org/licenses/by/4.0/), which permits use, duplication, adaptation, distribution and reproduction in any medium or format, as long as you give appropriate credit to the original author(s) and the source, provide a link to the Creative Commons license and indicate if changes were made.

The images or other third party material in this chapter are included in the work's Creative Commons license, unless indicated otherwise in the credit line; if such material is not included in the work's Creative Commons license and the respective action is not permitted by statutory regulation, users will need to obtain permission from the license holder to duplicate, adapt or reproduce the material.

\section{References}

Abdellatif M, Atherton W, Alkhaddar R, Osman Y (2014) Application of the UKCP09 WG outputs to assess performance of combined sewers system in a changing climate. J Hyd Eng, doi:10.1061/ (ASCE)HE.1943-5584.0001129

Allan JD, Palmer MA, Poff NL (2005) Climate change and freshwater ecosystems. In: Climate Change and Biodiversity. Yale University Press

Andersen HE, Kronvang B, Larsen SE, Hoffmann CC, Jensen TS, Rasmussen EK (2006) Climate-change impacts on hydrology and nutrients in a Danish lowland river basin. Sci Total Environ 65:223-237

Andréasson J, Bergström S, Gardelin M, German J, Gustavsson H, Hallberg K, Rosberg J (2011) Dimensionerande flöden för dammanläggningar för ett klimat $\mathrm{i}$ förändring - metodutveckling och scenarier [Design floods for dams in a changing climate methods and scenarios]. Elforsk rapport 11:25, Stockholm

Arnbjerg-Nielsen K (2012) Quantification of climate change effects on extreme precipitation used for high resolution hydrologic design. Urban Water J 9:57-65

Arnbjerg-Nielsen K, Fleischer HS (2009) Feasible adaptation strategies for increased risk of flooding in cities due to climate change. Water Sci Technol 60:273-281

Arnbjerg-Nielsen K, Willems P, Olsson J, Beecham S, Pathirana A, Bülow Gregersen I, Madsen H, Nguyen VTV (2013) Impacts of climate change on rainfall extremes and urban drainage systems: a review. Water Sci Technol 68:16-28
Arnell NW (2011) Uncertainty in the relationship between climate forcing and hydrological response in UK catchments. Hyd Earth Sys Sci 15:897-912

Arnell NW, Gosling SN (2016) The impacts of climate change on river flood risk at the global scale. Climatic Change 134(3):387-401

Ashley RM, Clemens FHLR, Tait SJ, Schellart A (2008) Climate change and the implications for modeling the quality of flow in combined sewers. Proceedings of the 11th International Conference on Urban Drainage, 31 August - 5 September 2008, Edinburgh, Scotland

Astaraie-Imani M, Kapelan Z, Fu G, Butler D (2012) Assessing the combined effects of urbanisation and climate change on the river water quality in an integrated urban wastewater system in the UK. J Environ Manage 112:1-9

Bastola S, Murphy C, Sweeney J (2011) The sensitivity of fluvial flood risk in Irish catchments to the range of IPCC AR4 climate change scenarios. Sci Total Environ 409:5403-5415.

Bates BC, Kundzewicz ZW, Wu S, Palutikof JP (eds) (2008) Climate change and water. Technical Paper of the Intergovernmental Panel on Climate Change, IPCC Secretariat, Geneva

Bell VA, Kay AL, Cole SJ, Jones RG, Moore RJ, Reynard NS (2012) How might climate change affect river flows across the Thames Basin? An area-wide analysis using the UKCP09 Regional Climate Model ensemble. J Hydrol 442-443:89-104

Boé J, Habets F (2013) Multi-decadal river flows variations in France. Hydrol Earth Syst Sc Disc 10:11861-11900

Boé J, Terray L, Martin E, Habets F (2009) Projected changes in components of the hydrological cycle in French river basins during the 21st century. Water Resour Res 45:W08426 doi:10.1029/ 2008WR007437

Boukhris O, Willems P, Vanneuville W (2008) The impact of climate change on the hydrology in highly urbanized Belgian areas. Proceedings International Conference on 'Water \& Urban Development Paradigms: Towards an integration of engineering, design and management approaches', Leuven, 15-17 September

Brisson E, Demuzere M, Willems P, van Lipzig N (2015) Assessment of natural climate variability using a weather generator. Clim Dynam 44:495-508

Brouyére S, Carabin G, Dassargues A (2004) Climate change impacts on groundwater resources: modelled deficits in a chalky aquifer, Geer basin, Belgium. Hydrogeol J 12:123-134

Cameron (2006) An application of the UKCIP02 climate change scenarios to flood estimation by continuous simulation for a gauged catchment in the northeast of Scotland, UK (with uncertainty). J Hydrol 328:212-226

Charlton MB, Arnell NW (2011) Adapting to climate change impacts on water resources in England - An assessment of draft Water Resources Management Plans. Global Environ Chang 21:238-248

Christierson BV, Vidal JP, Wade SD (2012) Using UKCP09 probabilistic climate information for UK water resource planning. J Hydrol 424-425:48-67

Chun KP, Wheater HS, Onof CJ (2009) Streamflow estimation for six UK catchments under future climate scenarios. Hydrol Res 40:96112

Cloke HL, Jeffers C, Wetterhall F, Byrne T, Lowe J, Pappenberger F (2010) Climate impacts on river flow: projections for the Medway catchment, UK, with UKCP09 and CATCHMOD. Hydrol Process 24:3476-3489

Collins M (2007) Ensembles and probabilities: a new era in the prediction of climate change. Phil Trans R Soc A 365:1957-1970

Dams J, Salvadore E, Van Daele T, Ntegeka V, Willems P, Batelaan O (2012) Spatio-temporal impact of climate change on the groundwater system. Hydrol Earth Syst Sc 16:1517-1531 
Dankers R, Feyen L (2008) Climate change impact on flood hazard in Europe: An assessment based on high-resolution climate simulations. J Geophys Res 113:D19105. doi:10.1029/2007JD009719

Dankers R, Arnell NW, Clark DB, Falloon PD, Fekete BM, Gosling SN, Heinke J, Kim H, Masaki Y, Satoh Y, Stacke T, Wada Y, Wisser D (2014) First look at changes in flood hazard in the Inter-Sectoral Impact Model Intercomparison Project ensemble. PNAS 111:3257-3261

de Wit M, Buiteveld H, van Deursen W (2007) Klimaatverandering en de afvoer van Rijn en Maas [Climate change and the discharge of the Rhine and Meuse]. Memo WRR/2007-006, RIZA, Netherlands

Diaz-Nieto J, Wilby RL (2005) A comparison of statistical downscaling and climate change factor methods: Impacts on low flows in the River Thames, United Kingdom. Climatic Change 69: 245-268

Ducharne A, Sauquet E, Habets F, Deque M, Gascoin S, Hachour A, Martin E, Oudin L, Page C, Terray L, Thiery D, Viennot P (2011) Evolution potentielle du régime des crues de la Seine sous changement climatique. Houille Blanche 1:51-57

EEA (2012) Climate change, impacts and vulnerability in Europe 2012: An indicated based report - Summary. European Environment Agency, Copenhagen

Feyen L, Dankers R (2009) Impact of global warming on streamflow drought in Europe. J Geophys Res 114:D17116. doi:10.1029/ 2008JD011438

Feyen L, Dankers R, Bódis K, Salamon P, Barredo JI (2012) Fluvial flood risk in Europe in present and future climates. Climatic Change 112:47-62

Fowler HJ, Kilsby CG (2007) Using regional climate model data to simulate historical and future river flows in northwest England. Climatic Change 80:337-367

Goderniaux P, Brouyére S, Fowler HJ, Blenkinsop S, Therrien R, Orban P, Dassargues A (2009) Large scale surface-subsurface hydrological model to assess climate change impacts on groundwater reserves. J Hydrol 373:122-138

Good P, Barring L, Giannakopoulos C, Holt T, Palutikof J (2006) Non-linear regional relationships between climate extremes and annual mean temperatures in model projections for 1961-2099 over Europe. Clim Res 31:19-34

Gosling S, Taylor RG, Arnell N, Todd MC (2011) A comparative analysis of projected impact of climate change on river runoff from global and catchment-scale hydrological models. Hydrol Earth Syst Sc 15:279-294

Gudmundsson L, Bremnes JB, Haugen JE, Engen-Skaugen T (2012a) Technical Note: Downscaling RCM precipitation to the station scale using statistical transformations - a comparison of methods. Hydrol Earth Syst Sc 16:3383-3390

Gudmundsson L, Tallaksen LM, Stahl K, Clark DB, Dumont E, Hagemann S, Bertrand N, Gerten D, Heinke J, Hanasaki N, Voss F, Koirala S (2012b) Comparing large-scale hydrological model simulations to observed runoff percentiles in Europe. J Hydrometeorol 13:604-620

Habets F, Boé J, Déqué M, Ducharne A, Gascoin S, Hachour A, Martin E, Pagé C, Sauquet E, Terray L, Thiéry D, Oudin L, Viennot P (2013) Impact of climate change on the hydrogeology of two basins in Northern France. Climatic Change 121:771-785

Hannaford J, Buys G, Stahl K, Tallaksen LM (2012) The influence of decadal-scale variability on trends in long European streamflow records. Hydrol Earth Syst Sc Disc 10:1859-1896

Hanson CE, Palutikof JP, Livermore MTJ, Barring L, Bindi M, Corte-Real J, Durao R., Giannakopoulos C, Good P, Holt T, Kundzewicz Z, Leckebusch GC, Moriondo M., Radziejewski M, Santos J, Schlyter P, Schwarb M, Stjernquist I, Ulbrich U (2007) Modelling the impact of climate extremes: an overview of the MICE project. Climatic Change 81:163-177
Henriques C, Holman IP, Audsley E, Pearn K (2008) An interactive multiscale integrated assessment of future regional water availability for agricultural irrigation in East Anglia and North West England. Climatic Change 90:89-111

Herrera-Pantoja M, Hiscock KM (2008) The effects of climate change on potential groundwater recharge in Great Britain. Hydrol Process 22:73-86

Hirabayashi Y, Mahendran R, Koirala S, Konoshima L, Yamazaki D, Watanabe S, Kim H, Kanae S (2013) Global flood risk under climate change. Nat Climate Chang 3:816-821

Huang S, Hattermann FF, Krysanova V, Bronstert A (2013) Projections of climate change impacts on river flood conditions in Germany by combining three different RCMs with a regional eco-hydrological model. Climatic Change 116:631-663

Hulme M, Jenkins GJ, Lu X, Turnpenny JR, Mitchell TD, Jones RG, Lowe J, Murphy JM, Hassell D, Boorman P, McDonald R, Hill S (2002) Climate Change Scenarios for the United Kingdom: The UKCIP02 Scientific Report. Tyndall Centre for Climate Change Research, School of Environmental Sciences, University of East Anglia, Norwich, UK

IPCC (2014) Climate Change 2014: Impacts, Adaptation, and Vulnerability. Part A: Global and Sectoral Aspects. Contribution of Working Group II to the Fifth Assessment Report of the Intergovernmental Panel on Climate Change - Chapter 3: Freshwater Resources. Intergovernmental Panel on Climate Change, University Press

Karlsson IB, Sonnenborg TO, Jensen KH, Refsgaard JC (2013) Evaluating the influence of long term historical climate change on catchment hydrology - using drought and flood indices. Hydrol Earth Syst Sc Disc 10:2373-2428

Kay AL, Jones DA (2012) Transient changes in flood frequency and timing in Britain under potential projections of climate change. Int $\mathrm{J}$ Climatol 32:489-502

Kay AL, Jones RG, Reynard NS (2006) RCM rainfall for UK flood frequency estimation. II. Climate change results. J Hydrol 318:163172

Kay AL, Davies HN, Bell VA, Jones RG (2009) Comparison of uncertainty sources for climate change impacts: flood frequency in England. Climatic Change 92:41-63

Kendon EJ, Roberts NM, Senior CA, Roberts MJ (2012) Realism of rainfall in a very high-resolution regional climate model. J Climate 25:5791-5806

Keupers I, Willems P (2013) Urbanization versus climate change: impact analysis on the river hydrology of the Grote Nete catchment in Belgium. Water Sci Technol 67:2670-2676

Kundzewicz ZW, Radziejewski M, Pinskwar I (2006) Precipitation extremes in the changing climate of Europe. Clim Res 31:51-58

Kundzewicz ZW, Kanae S, Seneviratne SI, Handmer J, Nicholls N, Peduzzi P, Mechler R, Bouwer LM, Arnell N, Mach K, Muir-Wood R, Brakenridge GR, Kron W, Benito G, Honda Y, Takahashi K, Sherstyukov B (2013) Flood risk and climate change: global and regional perspectives. Hydrolog Sci J 59:1-28

Larsen AN, Gregersen IB, Christensen OB, Linde JJ, Mikkelsen PS (2009) Potential future increase in extreme one-hour precipitation events over Europe due to climate change. Water Sci Technol 60:2205-2216

Lawrence D, Hisdal H (2011) Hydrological projections for floods in Norway under a future climate. Report no. 5-2011, Norwegian Water Resources and Energy Directorate

Lawrence D, Haddeland I, Langsholt E (2009) Calibration of HBV hydrological models using PEST parameter estimation. Report no. 1-2009, Norwegian Water Resources and Energy Directorate

Leander R, Buishand TA, van den Hurk BJJM, de Wit MJM (2008) Estimated changes in flood quantiles of the river Meuse from resampling of regional climate model output. J Hydrol 351:331-343 
Lenderink G, Buishand A, van Deursen W (2007) Estimates of future discharges of the river Rhine using two scenario methodologies: direct versus delta approach. Hydrol Earth Syst Sc 11:1145-1159

Maraun D, Wetterhall F, Ireson AM, Chandler RE, Kendon EJ, Widmann M, Brienen S, Rust HW, Sauter T, Themeß1 M, Venema VKC, Chun KP, Goodess CM, Jones RG, Onof C, Vrac M, Thiele-Eich I (2010) Precipitation downscaling under climate change: Recent developments to bridge the gap between dynamical models and the end user. Rev Geophys, AGU, 48: RG3003. doi:10.1029/2009RG000314

Mark O, Svensson G, König A, Linde JJ (2008) Analyses and adaptation of climate change impacts on urban drainage systems. Proceedings of the 11th International Conference on Urban Drainage, 31 August - 5 September 2008, Edinburgh, Scotland

May W (2008) Potential future changes in the characteristics of daily precipitation in Europe simulated by the HIRHAM regional climate model. Clim Dynam 30:581-603

MetOffice (2011) Climate: Observations, projections and impacts, Subreports for United Kingdom, France, Germany. UK MetOffice

Minville M, Brissette F, Leconte R (2008) Uncertainty of the impact of climate change on the hydrology of a Nordic watershed. J Hydrol 358:70-83

Monbaliu J, Chen Z, Felts D, Ge J, Hissel F, Kappenberg J, Narayan S, Nicholls RJ, Ohle N, Schuster D, Sothmann J, Willems P (2014) Risk assessment of estuaries under climate change: lessons from Western Europe. Coast Eng 87:32-49

Murphy JM, Sexton DMH, Jenkins GJ, Booth BBB, Brown CC, Clark RT, Collins M, Harris GR, Kendon EJ, Betts RA, Brown SJ, Humphrey KA, McCarthy MP, McDonald RE, Stephens A, Wallace C, Warren R, Wilby R, Wood RA (2009) Climate change projections. UK Climate Projections Science Report. UK Met Office Hadley Centre

New M, Cuellar M, Lopez A (2007) Probabilistic regional and local climate projections: false dawn for impacts assessment and adaptation? In: Integrating Analysis of Regional Climate Change and Response Options, Nadi, Fiji

Nie L, Lindholm O, Lindholm G, Syversen E (2009) Impacts of climate change on urban drainage systems - a case study in Fredrikstad, Norway. Urban Water J 6:323-332

Niemczynowicz J (1989) Impact of the greenhouse effect on sewerage systems - Lund case study. Hydrolog Sci J 34:651-666

Ntegeka V, Willems P, Monbaliu J (2011) Incorporating the correlation between upstream inland, downstream coastal and surface boundary conditions into climate scenarios for flood impact analysis along the river Scheldt. Geophysical Research Abstracts, EGU2011-6554: EGU General Assembly 2011, Vienna, April 2011

Ntegeka V, Decloedt LC, Willems P, Monbaliu J (2012) Quantifying the impact of climate change from inland, coastal and surface conditions. In: Comprehensive Flood Risk Management - Research for Policy and Practise (Klijn F, Schweckendiek T, eds), CRC Press

Ntegeka V, Baguis P, Roulin E, Willems P (2014) Developing tailored climate change scenarios for hydrological impact assessments. J Hydrol 508:307-321

Olsson J, Berggren K, Olofsson M, Viklander M (2009) Applying climate model precipitation scenarios for urban hydrological assessment: A case study in Kalmar City, Sweden. Atmos Res 92:364-375

Olsson J, Dahné J, German J, Westergren B, von Scherling M, Kjellson L, Ohls F, Olsson A (2010) A study of future discharge load on Stockholm's main sewer system, SMHI Reports Climatology 3 (in Swedish)

Palmer TN, Räisänen J (2002) Quantifying the risk of extreme seasonal precipitation events in a changing climate. Nature 415:512-514
Pfister L, Kwadijk J, Musy A, Bronstert A, Hoffmann L (2004) Climate change, land use change and runoff prediction in the Rhine-Meuse basins. River Res Appl 20:229-241

Plosz BG, Liltved H, Ratnaweera H (2009) Climate change impacts on activated sludge wastewater treatment: a case study from Norway. Water Sci Technol 60:533-541

Prudhomme C, Williamson J, Parry S, Hannaford J (2012) Projections of flood risk in Europe. In: Changes in Flood Risk in Europe, CRC Press

Prudhomme C, Giuntoli I, Robinson EL, Clark DB, Arnell NW, Dankers R, Fekete BM, Franssen W, Gerten D, Gosling SN, Hagemann S, Hannah DM, Kim H, Masaki Y, Satoh Y, Stacke T, Wada Y, Wisser D (2014) Hydrological droughts in the 21st century, hotspots and uncertainties from a global multimodel ensemble experiment. PNAS 111:3262-3267

Raupach MR, Marland G, Ciais P, Le Quéré C, Canadell JG, Klepper G, Field CB (2007) Global and regional drivers of accelerating $\mathrm{CO}_{2}$ emissions. Proc Nat Acad Sci 104:10288-10293

Refsgaard JC, Madsen H, Andréassian V, Arnbjerg-Nielsen K, Davidson TA, Drews M, Hamilton D, Jeppesen E, Kjellström E, Olesen JE, Sonnenborg TO, Trolle D, Willems P, Christensen JH (2014) A framework for testing the ability of models to project climate change and its impacts. Climatic Change 122:271-282

Rojas R, Feyen L, Dosio A, Bavera D (2011) Improving pan-European hydrological simulation of extreme events through statistical bias correction of RCM-driven climate simulations. Hydrol Earth Syst Sc 15:2599-2620

Rojas R, Feyen L, Bianchi A, Dosio A (2012) Assessment of future flood hazard in Europe using a large ensemble of bias corrected regional climate simulations. J Geophys Res 117:D17109. doi:10. 1029/2012JD017461

SAWA (2012) Climate change impacts and uncertainties in flood risk management: Examples from the North Sea Region. Report no. $05-$ 2012 of SAWA Interreg IVB Project, Norwegian Water Resources and Energy Directorate

Schneider C, Laizé CLR, Acreman MC, Flörke M (2013) How will climate change modify river flow regimes in Europe? Hydrol Earth Syst Sc 17:325-339

Seibert J (2003) Reliability of model predictions outside calibration conditions. Nordic Hyd 34:477-492

Semadeni-Davies A, Hernebring C, Svensson G, Gustafsson LG (2008) The impacts of climate change and urbanisation on drainage in Helsingborg, Sweden: Combined sewer system. J Hydrol 350:100113

Semenov MA, Stratonovitch P (2010) Use of multi-model ensembles from global climate models for assessment of climate change impacts. Clim Res 41:1-14

Shabalova MV, van Deursen WP, Buishand TA (2003) Assessing future discharge of the river Rhine using regional climate model integrations and a hydrological model. Clim Res 23:233-246

Shaffrey LC, Stevens I, Norton WA, Roberts MJ, Vidale PL, Harle JD, Jrrar A, Stevens DP, Woodage MJ, Demory ME, Donners J, Clark DB, Clayton A, Cole JW, Wilson SS, Connolley WM, Davies TM, Iwi AM, Johns TC, King JC, New AL, Slingo JM, Slingo A, Steenman-Clark L, Martin GM, (2009) UK HiGEM: The new UK High-resolution Global Environment Model - Model description and basic evaluation. J Climate 22:1861-1896

Smith JB, Schneider SH, Oppenheimer M, Yohe GW, Hare W, Mastrandrea MD, Patwardhan A, Burton I, Corfee-Morlot J, Magadza CHD, Füssel HM, Pittock AB, Rahman A, Suarez A, van Ypersele JP (2009) Assessing dangerous climate change through an update of the Intergovernmental Panel on Climate Change (IPCC) "reasons for concern". PNAS 106:4133-4137 
Smith A, Freer J, Bates P, Sampson C (2014) Comparing ensemble projections of flooding against flood estimation by continuous simulation. J Hydrol 511:205-219

Stahl K, Hisdal H, Hannaford J, Tallaksen LM, van Lanen HAJ, Sauquet E, Demuth S, Fendekova M, Jódar J (2010) Streamflow trends in Europe: evidence from a dataset of near-natural catchments. Hydrol Earth Syst Sc 14:2367-2382

Stahl K, Tallaksen LM, Hannaford J, van Lanen HAJ (2012) Filling the white space on maps of European runoff trends: estimates from a multi-model ensemble. Hydrol Earth Syst Sc 16:2035-2047

Tait SJ, Ashley RM, Cashman A, Blanksby J, Saul AJ (2008) Sewer system operation into the 21 st century, study of selected responses from a UK perspective. Urban Water J 5:77-86

Tavakoli M, De Smedt F, Vansteenkiste Th, Willems P (2014) Impact of climate change and urban development on extreme flows in the Grote Nete watershed, Belgium. Nat Hazards 71:2127-2142

Tebaldi C, Smith R, Nychka D, Mearns L (2005) Quantifying uncertainty in projections of regional climate change: a Bayesian approach to the analysis of multi-model ensembles. J Climate 18:1524-1540

Teutschbein C, Seibert J (2012) Bias correction of regional climate model simulations for hydrological climate-change impact studies: Review and evaluation of different methods. J Hydrol 456-457:12-29

Teutschbein C, Wetterhall F, Seibert J (2011) Evaluation of different downscaling techniques for hydrological climate-change impact studies at the catchment scale. Clim Dynam 37:2087-2105

Thodsen H (2007) The influence of climate change on stream flow in Danish rivers. J Hydrol 333:226-238

Thompson JR, Gavin H, Refsgaard A, Refstrup Sørenson H, Gowing DJ (2009) Modelling the hydrological impacts of climate change on UK lowland wet grassland. Wetl Ecol Manag 17:503-523

van den Hurk B, Tank AK, Lenderink G, van Ulden A, van Oldenborgh GJ, Katsman C., van den Brink H, Keller F, Bessembinder J, Burgers G, Komen G, Hazeleger W, Drijfhout S (2006) KNMI Climate Change Scenarios 2006 for the Netherlands, KNMI Scientific Report WR 2006-01, KNMI, De Bilt, The Netherlands

Van der Linden P, Mitchell JFB (2009) ENSEMBLES: Climate Change and its Impacts: Summary of research and results from the ENSEMBLES project, UK Met Office Hadley Centre

van Huijgevoort MHJ, van Lanen HAJ, Teuling AJ, Uijlenhoet R (2014) Identification of changes in hydrological drought characteristics from a multi-GCM driven ensemble constrained by observed discharge. J Hydrol 512:421-434

van Oldenborgh GJ, Drijfhout S, Ulden A, Haarsma R, Sterl A, Severijns C, Hazeleger W, Dijkstra H (2009) Western Europe is warming much faster than expected. Clim Past 5:1-12

van Pelt SC, Beersma JJ, Buishand TA, van den Hurk, BJJM, Kabat P (2012) Future changes in extreme precipitation in the Rhine basin based on global and regional climate model simulations. Hydrol Earth Syst Sc 16:4517-4530

Van Steenbergen N, Willems P (2012) Method for testing the accuracy of rainfall-runoff models in predicting peak flow changes due to rainfall changes, in a climate changing context. J Hydrol 414-415:425-434

Vansteenkiste Th, Tavakoli M, Ntegeka V, Willems P, De Smedt F, Batelaan O (2013) Climate change impact on river flows and catchment hydrology: a comparison of two spatially distributed models. Hydrol Process 27:3649-3662

Vansteenkiste Th, Tavakoli M, Ntegeka V, De Smedt F, Batelaan O, Pereira F, Willems P (2014) Intercomparison of hydrological model structures and calibration approaches in climate scenario impact projections. J Hydrol 519:743-755

Vidal JP, Wade SD (2008) Multimodel projections of catchment-scale precipitation regime. J Hydrol 353:143-158

Vörösmarty CJ, McIntyre PB, Gessner MO, Dudgeon D, Prusevich A, Green P, Glidden S, Bunn SE, Sullivan CA, Liermann CR, Davies PM (2010) Global threats to human water security and river biodiversity. Nature 467:555-561

Ward PJ, Jongman B, Weiland FS, Bouwman A, van Beek R, Bierkens PFP, Ligtvoet W, Winsemius HC (2013) Assessing flood risk at the global scale: model setup, results and sensitivity. Env Res Lett 8:044019. doi:10.1088/1748-9326/8/4/044019

Warren R, Arnell N, Berry P, Brown S, Dicks L, Gosling S, Hankin R, Hope C, Lowe J, Matsumoto K, Masui T, Nicholls R, O'Hanley J, Osborn T, Scriecru S (2010) The economics and climate change impacts of various greenhouse gas emissions pathways: A comparison between baseline and policy emissions scenarios. Work stream 1, Deliverable 3, Report 1 of the AVOID programme (AV/WS1/D3/R01)

Weisse R, Bellafiore D, Menendez M, Mendez F, Nicholls R, Umgiesser G, Willems P (2014) Changing extreme sea levels along European coasts. Coast Eng 87:4-14

Willems P (2009) A time series tool to support the multi-criteria performance evaluation of rainfall-runoff models. Environ Modell Softw 24:311-321

Willems P (2013a) Revision of urban drainage design rules after assessment of climate change impacts on precipitation extremes at Uccle, Belgium. J Hydrol 496:166-177

Willems P (2013b) Multidecadal oscillatory behaviour of rainfall extremes in Europe. Climatic Change 120:931-944

Willems P, Arnbjerg-Nielsen K, Olsson J, Nguyen VTV (2012a) Climate change impact assessment on urban rainfall extremes and urban drainage: methods and shortcomings. Atmos Res 103:106118

Willems P, Olsson J, Arnbjerg-Nielsen K, Beecham S, Pathirana A, Bülow Gregersen I, Madsen H, Nguyen VTV (2012b) Impacts of Climate Change on Rainfall Extremes and Urban Drainage. IWA Publishing

Zhou Q, Mikkelsen PS, Halsnæs K, Arnbjerg-Nielsen K (2012) Framework for economic pluvial flood risk assessment considering climate change effects and adaptation benefits. J Hydrol 414-415:539-549 